\title{
Green Illusions: Governing CSR Aesthetics
}

\section{Benjamin J. Richardson*}

This article makes a novel argument that governance of corporate environmental activities should recognize that the business corporation is an aesthetic phenomenon, including the environmental practices and communications undertaken in the name of "corporate social responsibility" [CSR]. Corporate identities and CSR practices are aesthetically projected through logos, trademarks, websites, the presentation of products and services, stylish offices, company uniforms, and other aesthetic artefacts. This corporate "branding" dovetails with the broader aestheticization of our pervasive media and consumer culture. Aesthetics has particular salience in CSR for influencing, and sometimes misleading, public opinion about corporate environmental performance. Consequently, in disciplining unscrupulous corporate behaviour, governance methods must be more responsive to such aesthetic characteristics. The green illusions of business communications create difficulties for regulation, which is better suited to disciplining discrete misleading statements about retailed products or trademarks rather than tackling the broader aesthetic character of business and the marketplace. The article suggests that non-state actors who are more sensitive to aesthetics can help to fill some of this governance void. The "counter-aesthetic" strategies of social and environmental activist groups can inject a subversive narrative that can help to unmask these green illusions. Although the history of such tactics suggests they probably have only a modest effect in challenging corporate deception, the law can assist by protecting public spaces from corporate marketing and sponsorship.

Cet article présente une argumentation novatrice selon laquelle la gouvernance des activités pro-environnementales des entreprises devrait reconnaître que la société commerciale est un phénomène esthétique, notamment au chapitre des pratiques et opérations de communication environnementales mises en ceuvre au nom de la "responsabilité sociale de l'entreprise ». L'identité de l'entreprise et ses pratiques en matière de responsabilité sociale sont projetées esthétiquement dans les logos, les marques déposées, les sites internet, dans la présentation des produits et services proposés, dans des bureaux aménagés avec style, les uniformes de ses employés et d'autres objets de facture esthétique. Cette stratégie de marque s'inscrit dans l'esthétisation générale de la culture médiatique et de consommation envahissante qui est la nôtre. En matière de responsabilité sociale de l'entreprise, l'esthétique a une importance particulière parce qu'elle sert à influencer et parfois à berner l'opinion publique quant au bilan environnemental d'une entreprise. En conséquence, pour corriger une conduite peu scrupuleuse de l'entreprise, les méthodes de gouvernance doivent être mieux adaptées à ce type de caractéristiques esthétiques. Les vertes illusions des communications d'entreprise compliquent la réglementation, qui convient mieux pour sanctionner les 
discrètes affirmations trompeuses portant sur les produits vendus au détail ou sur les marques déposées que pour s'attaquer au caractère esthétique général des affaires et du marché. L'article laisse entendre que les acteurs non étatiques dotés d'une sensibilité supérieure à l'esthétique peuvent contribuer à combler un peu ce vide de gouvernance. Les stratégies de "contre-esthétique » des groupes militants sociaux et écologistes peuvent introduire un discours subversif qui aide à démasquer ces vertes illusions. Bien que l'histoire de telles tactiques donne à penser qu'elles n'ont probablement qu'un effet limité sur la remise en cause de la tromperie des entreprises, le droit peut offrir un soutien en protégeant les espaces publics contre le marketing et la commandite d'entreprise.

\section{ORIENTATION}

Many older people remember the iconic "Crying Indian" advertisement, released on television by the Keep America Beautiful campaign on Earth Day on 22 April 1971. Widely regarded as one of the best marketing campaigns of the twentieth century, the sixty-second clip features an actor in Native American attire paddling a canoe, initially through an unspoiled waterway that presumably signifies a pristine past. ${ }^{1}$ As the canoeist travels further, the water becomes increasingly polluted, and he eventually enters a dirty industrial port. Pulling his canoe ashore, the Indian strides towards a busy highway where a passing motorist tosses a bag of trash that splatters on the Indian's moccasins. With a sonorous voice, the narrator exclaims: "[S]ome people have a deep, abiding respect for the natural beauty that was once this country. And some people don't." But with only twenty-seven words spoken, the message and strength of the advertisement rests primarily on its aesthetic effects: the varied imagery and skilful photography set to a pulsating soundtrack of beating drums progressively overlaid with a chorus of trombones and trumpets. The advertisement was hugely successful for Keep America Beautiful, soliciting massive public awareness and support for its cause.

The Crying Indian advertisement, however, was disingenuous. Apart from the fact that an Italian American actor wearing a wig played the Indian, the Keep America Beautiful campaign was created with major beverage and packaging businesses who wanted to obfuscate their responsibility. The ad was released at a time when the environmental movement in the United States was becoming more assertive against industry, which needed to shift the public perception. The advertisement finishes with a close-up of the Indian's face shedding a single tear, with the narrator declaring: "[P] eople start pollution, and people can stop it." By focusing on uncouth litterbugs, the ad placed responsibility in the hands of individuals while deflecting attention from the corporate polluters. Indeed, the businesses associated with the campaign kept a low profile, leaving the public to believe that corporate America was a disinterested bystander. Unsurprisingly, contemporary Americans are far more wasteful than they were in the early 1970s, with the average citizen in 2012 generating 4.38 pounds of trash every day compared to 3.25 pounds in $1970 .^{2}$

* Benjamin J. Richardson, Professor of Environmental Law, Faculty of Law and Institute for Marine and Antarctic Studies, University of Tasmania, Hobart, Australia.

1 The advertisement can be viewed online: Youtube <www.youtube.com/watch?v=j7OHG7tHrNM>.

2 Environmental Protection Agency, "Municipal Solid Waste Generation, Recycling, and Disposal in the United States:

Facts and Figures for 2012" at 1, online: <www.epa.gov/sites/production/files/2015-09/documents/2012_msw_fs.pdf >. 
The deceptive environmental marketing of the 1970s persists today, using similar visual, acoustic, and other sensory effects to engage the public as effectively as in the Crying Indian commercial. When companies try to impress the public with their environmental performance, bragging about their low carbon footprint or other supposed green credentials, they frequently embellish their claims with appealing aesthetic artefacts. Corporate sustainability reports bristling with technical data are seemingly not enough to win people over. Instead, the public might see Renault's Twingo "eco" car, which in one advertisement was pictured with leaves blowing from its exhaust, BP's stylized sunflower corporate logo, or the choir singing along to Fiji Water's commercial for the "Earth's finest water." Colloquially, these displays are sometimes derided as "greenwashing." They are not merely the products of creative marketing teams but, rather, reflect the deeply aesthetic character of the modern business corporation and the consumer economy in which it operates.

How should we critically evaluate the aesthetics of so-called corporate social responsibility [CSR] from the standpoint of ensuring accountability in businesses' environmental practices? And what do aesthetics specifically bring to the analysis of CSR governance? These enquiries shape this article, which argues that we need to conceive of the corporation and its environmental practices as having aesthetic characteristics in order to properly understand their societal impact and the appropriate governance response. Contrary to the dominant narratives about the virtues of aesthetic appreciation, notably for emotional gratification and moral improvement, ${ }^{3}$ this article equally highlights their negative connotations in the world of business. When captivated by alluring beauty, people may be induced to act in ways they regret on more sober reflection. When these aesthetic charms camouflage environmental injury, at stake is much more than a tinge of remorse. We need to look beyond official regulatory responses to corporate deception, such as controls on misleading advertising, to governance strategies that I call "counter-aesthetics." As promoted by dissent artists and activists, this strategy has some capacity, which has already been demonstrated, to unmask specious CSR aesthetics.

"Aesthetics" originated in the ancient Greek word aisthetikos, which relates to a human being's sensory perception. In contemporary English usage, it refers adjectivally to the values given to sensual experiences, such as the aesthetic appreciation of picturesque scenery or uplifting music, and, as a noun, it denotes the principles or philosophy of aesthetic judgments especially relating to fine art and beauty. ${ }^{4}$ With the "aestheticization of daily life" that is evident in many societies, ${ }^{5}$ especially in the mass media and consumer culture, scholars increasingly extend the study of aesthetics to a plethora of expressive activities including business communications. ${ }^{6}$ In this broader guise, aesthetics covers numerous sensual experiences and contexts, ${ }^{7}$ and, thus, we are seemingly reverting to the etymology of the word aesthetics pertaining to sensory perception. This article embraces this broad terminology.

For business operators, aesthetic values serve not only to slant how the public perceives their environmental or social activities but also the corporation itself as an aesthetic phenomenon. Unlike a human being, the "distinguishing feature of the body corporate is its invisibility," explains law professor

Damien Freeman, Art's Emotions: Ethics, Expression and Aesthetic Experience (New York: Routledge, 2012).

4 Andrew Light \& Jonathan Smith, eds, The Aesthetics of Everyday Life (New York: Columbia University Press, 2005);

Robert Steckler, Aesthetics and the Philosophy of Art (Lanham, MD: Rowman \& Littlefield Publishers, 2010).

5 Jean Baudrillard, Simulations (Boston: MIT Press, 1983).

6 Gerald Mazzalovo, Brand Aesthetics (New York: Palgrave Macmillan, 2012) at 1.

7 Antonio Strati, Organization and Aesthetics (London: Sage, 1999) at 184-188. 
Leslie Moran. ${ }^{8}$ Often lacking a discrete, visible physical presence, especially for the large, multinational corporation, a business is experienced by the public indirectly and aesthetically through its aural and visual logos and websites, the advertising and packaging of its products and services, as well as its stylish corporate offices, among many ways of projecting business identity. ${ }^{9}$ The corporation, thus, is not only seemingly everywhere but also in a sense nowhere, without connection to any specific place.

The importance of aesthetic artefacts to corporate identity is tied to the broader aestheticization of our post-modernizing world. French sociologist Jean Baudrillard coined the notion of "hyper-reality" to describe this milieu, habitually associated with shopping malls, amusement parks, television reality shows, tabloid celebrity gossip, social media, and other realms where consumers are saturated by spectacles and "simulacra." 10 Philosopher Umberto Eco observes that people desire to consume or experience this hyperreality as though it is an authentic expression of life. Like the advent of "fake news" that has stained Donald Trump's presidency, this culture of illusion obfuscates the meaning of the external reality that lies behind such simulations. ${ }^{11}$ As Baudrillard puts it, "we live in a world where there is more and more information, and less and less meaning." 12 Hyper-reality relatedly thus also obfuscates our capacity to make normative judgments. This aestheticization of life can make it difficult to identify and control deceptive business aesthetics, as we are no longer dealing with just misleading advertising of goods, but the corporations themselves and the marketplace as a whole are blurred into this hyper-reality. This aestheticization of consumerism is also recognized in official circles; a report by the US government surveying changes in the American economy from 1901 to 2003 remarked that "mass consumption, spurred by advertising and consumer credit, has become a distinguishing characteristic of modern society." 13

While the law may discipline overtly misleading marketing, the larger aesthetic qualities of the business world and their role in fuelling environmentally degrading consumption are less amenable to traditional methods of legal scrutiny. Corporate logos, websites, and other aesthetic expressions have subtle and nuanced connotations to which the law - a highly text-based discipline - is less responsive. Beyond the state, however, counter-aesthetic strategies led by artists allied with environmental activists may help to unmask green illusions, by interpolating a dissenting narrative that can help consumers to be more discerning about corporate practices. Impersonating corporate personalities, reconfiguring logos, manipulating websites, defacing billboards, and caricaturing advertisements to subvert their messages are the methods of aesthetic sabotage, also known as "culture jamming," that this article examines. It will also argue that the law cannot be a bystander to counter-aesthetics, as it must make decisions on whether public spaces will be protected from expropriation by business and uphold activists' freedoms of expression.

8 Leslie Moran, “'Skeleton Arguments': The Art of Corporate Criminal Capacity” in Roberta Kevelson, ed, Law and Aesthetics (New York: Peter Lang, 1992) 303 at 307.

9 Philip Hancock, "Aesthetics and Aestheticization" in P Hancock \& A Spicer, eds, Understanding Corporate Life (London: Sage, 2009) 46 at 51-52.

10 Jean Baudrillard, "The Hyper-Realism of Simulation" in C Harrison \& P Wood, eds, Art in Theory 1900-1990: An Anthology of Changing Ideas (Oxford: Blackwell, 1990) 1049.

11 Umberto Eco, Travels in Hyper-reality (London: Pan Books, 1987).

12 Jean Baudrillard, Simulacra and Simulation, translated by SF Glaser (Ann Arbor: University of Michigan Press, 1994) at 79.

13 Elaine Chao \& Kathleen Utgoff, 100 Years of US Consumer Spending, Data for the Nation, New York City, and Boston (Washington, DC: US Department of Labor, May 2006) at 1. 
Although this article excoriates the corporate sector, we should remember that governments themselves are no strangers to artful manipulation. Propaganda has long been a contrivance of totalitarian regimes to sway the hoi polloi ${ }^{14}$ and, indeed, all governments use aesthetic strategies in some ways to cultivate a favourable public impression. Many also use green-washed imagery in their expressions of national identity, such as the environmental motifs depicted in their currency, flags, maps, coats of arms, monuments, and national anthems, in addition to the hyped eco-tourism marketing they occasionally sponsor. ${ }^{15}$ Some of the advice later in this article about counter-aesthetics, thus, is as applicable to the government sector as to business.

With this orientation, the remainder of this article unfolds over five sections. Part II introduces the conceptual and methodological framework for evaluating CSR aesthetics. From this foundation, Part III examines the aesthetic dimensions of business and the consumer economy, including the green-washed aesthetics of CSR itself and the aesthetic qualities of CSR terminology and discourse. Governing green illusions is the focus of Parts IV and V, with the former looking at traditional regulatory controls, including in regard to misleading advertising, and the latter assessing counter-aesthetic strategies by non-state actors. The article closes in Part VI with reflections on how the law might aid counter-aesthetics by protecting the public sphere. Throughout, the article canvasses examples from a variety of jurisdictions but predominantly, in particular, Anglo-American countries. Because the subject matter and argument of this article is unfamiliar to most business law and CSR scholars, it adopts a broad inquiry covering overarching themes and representative examples rather than providing a single case study or focusing on any individual jurisdiction.

\section{AESTHETICS AND ART: MODES OF ENQUIRY}

How should we critique CSR aesthetics? Colloquial definitions of aesthetic experiences that focus on the variety of sensory stimulations that the human body can feel ${ }^{16}$ would hardly guide one on how to critically evaluate the purpose, influence, and impact of aesthetics in the marketplace. While the physical world provides the raw material for sensual experiences - from the properties of an artwork to the textures of a landscape - their aesthetic qualities are not wholly independent from observers. Culture and cognition mediates aesthetic judgments, as shown in how patriarchal and racist prejudices have influenced perceptions of human beauty. ${ }^{17}$ Aesthetic preferences also matter in CSR because what might appear to one observer to be an environmentally credible commercial for an "eco-friendly" hybrid car cruising through scenic countryside might for another critical viewer seem incredulous. The study of aesthetics thus grapples with how to reconcile the ideal of universal, ahistorical principles for determining the merit of aesthetic judgments with our subjective and cultural context.

14 See generally Jonathan Auerbach \& Russ Castronovo, eds, The Oxford Handbook of Propaganda Studies (Oxford: Oxford University Press, 2013).

15 New Zealand is a pertinent example. NJ Morgan, A Pritchard \& R Piggott, "New Zealand, 100\% Pure: The Creation of a Powerful Niche Destination Brand" (2002) 9:4-5 Journal of Brand Management 335.

16 For instance, one commentator defines aesthetic experiences as "how the world strikes the body on its sensory surfaces, of what takes roots in the gaze and the guts and all that arises from our banal, biological insertion into the world." Terry Eagleton, The Ideology of the Aesthetic (Oxford: Basil Blackwell, 1990) at 13.

17 Naomi Wolf, The Beauty Myth (London: Chatto \& Windus, 1990); David Wiley, "Beauty and Beast: Physical Appearance Discrimination in American Criminal Trials" (1995-1996) 27 St Mary's LJ 193. 
Efforts to put human sensuality on a rational and objective footing began during the Enlightenment, most assertively with Immanuel Kant's Critique of Judgement published in $1790 .{ }^{18} \mathrm{He}$ suggested that aesthetics could be taken beyond the realm of personal experiences if one adopts a "disinterested" judgment, untainted by instrumental or utilitarian motives, thereby enabling individuals to share such experiences and evaluate them communally. ${ }^{19}$ Although influential for understanding some forms of aesthetic appreciation, Kantian philosophy fails to aid the understanding of many everyday sensory experiences in the contemporary world. Disinterested aesthetic judgment might be credible for admiring a Rembrandt or a Vermeer masterpiece at the Rijksmuseum, but it becomes problematic once we recognize how aesthetic experiences infuse daily living, from shopping to working, that do not involve "disinterestedness." ${ }^{20}$ Equally apropos, the public reactions to CSR marketing can hardly be analyzed through a Kantian framework. If they were judged purely for their artistic merit, such as the quality of the photography or the music in corporate marketing, "disinterested" criteria might be appropriate, but they are not once we shift our vital enquiry to the underlying agenda and impact of CSR communications.

An alternate mode of enquiry concentrates on the psychology of aesthetic appreciation, looking for correlations between mental or emotional reactions to sensory stimuli. ${ }^{21}$ By investigating empirically individuals' reactions to shapes, sounds, colours, and other aesthetic attributes of art or everyday objects, these enquiries seek to delineate common bases to aesthetic appreciation. Gustav Theodor Fechner pioneered this field in the nineteenth century and corroborated, for instance, the "golden ratio" hypothesis that supposedly correlates with commonly held perceptions of beauty in the human body, architecture, and other forms. ${ }^{22}$ In recent decades, scholars have also evaluated aesthetics through the lens of evolutionary psychology, postulating that some human psychological traits, such as aesthetic preferences for beautiful mates or landscape habitats, reflect deeply evolved adaptations to humans' ancestral conditions. ${ }^{23}$ The foregoing framework may help to identify the aesthetic properties of corporate communications that most influence business customers, perhaps owing to the symmetry of logos or colours of product packaging. Yet it does not help to assess whether corporate aesthetic practices are socially appropriate, such as whether they reveal accurate information about businesses' environmental performance or positively influence consumers' environmental behaviour.

More promising avenues of enquiry for this article's subject are the philosophies of environmental aesthetics and everyday aesthetics as well as the theories of environmental art criticism. Given that CSR communications often depict images or sounds associated with beautiful scenery, charismatic wildlife, or other nature motifs, presumably for persuading the public that the sponsoring companies are eco-friendly, insights from environmental aesthetics might help to assess whether those CSR expressions are appropriate. One important theory of environmental aesthetics is the "cognitive model." Associated primarily with the work of Allen Carlson, it postulates that proper aesthetic comprehension requires some

18 Edmund Burke, A Philosophical Inquiry into the Origin of Ours Ideas of the Sublime and Beautiful (Oxford: Oxford University Press, 2015).

19 Immanuel Kant, Critique of Judgment, translated by JH Bernard (New York: Cosimo, 2007).

20 Andrew Light \& Jonathan Smith, eds, The Aesthetics of Everyday Life (New York: Columbia University Press, 2005).

21 See Pablo PL Tinio \& Jeffrey K Smith (eds), The Cambridge Handbook of the Psychology of Aesthetics and the Arts (Cambridge, UK: Cambridge University Press, 2017).

22 Gustav Theodor Fechner, Vorschule der Aesthetik (Leipzig: Breitkopf \& Härtel, 1876).

23 Marcos Nadal \& Gerardo Gmez-Puerto, "Evolutionary Approaches to Art and Aesthetics" in Tinio \& Smith, supra note 21, at 167 . 
knowledge of the natural sciences that guides the viewer to the appropriate elements of aesthetic significance, such as that associated with the botanical or zoological features of biodiversity. ${ }^{24} \mathrm{On}$ this basis, we might infer that the public is best placed to judge CSR aesthetics where individuals possess some basic scientific knowledge about the environmental issues, such as climate change or biodiversity values, that are addressed by CSR practices. Such knowledge might thereby strengthen viewers' capacity to critically evaluate green-washed marketing about "carbon neutrality" or "eco-friendly" products. In other words, public environmental education might critically enhance and filter viewers' interpretation of CSR aesthetics.

Since CSR aesthetics and corporate identity have become so deeply embedded in our consumer economy, it is also helpful to understand that aesthetic experiences are not confined to art galleries or visiting scenic landscapes but, rather, inhabit our daily lives. Some aestheticians, notably Yuriko Saito and Andrew Light, advocate an "everyday aesthetics" that illuminates how "aesthetic practices permeate people's daily lives" through ordinary objects and activities from shopping to dining. ${ }^{25}$ The spaces where people come together are vital for such "everyday" experiences, contributing to the aesthetic "atmosphere" that Gernot Böhme and others have argued should be recognized as an aesthetic realm. ${ }^{26} \mathrm{~A}$ shopping plaza, courtroom, or any other communal space can be assessed for its visual, acoustic, and other sensory qualities that create an overall aesthetic atmosphere. The type of atmosphere affects participants' aesthetic experiences; the encroachment of consumerism and corporate advertising into public spaces can thus be understood as changing their atmosphere.

Also of value to the appraisal of CSR aesthetics is the literature on environmental art criticism, given that CSR communications are ubiquitously conveyed through film, photography, design, and music. The criteria by which we evaluate museum art should differ from CSR artefacts, as the latter are intended by the sponsoring companies not to be admired with Kantian "disinterestedness" but, rather, to encourage shopping and consuming. The modernist trope of art as a medium of an autonomous and self-determined subject not only ignores the long history of art serving wider societal needs, such as religious art commissioned by the churches, but it also fails to provide a framework for understanding the purpose and effects of CSR artefacts. Instead, an "eco-critical" approach as recommended by Alan Braddock should be useful, as it emphasizes the need to assess art with reference to criteria of "environmental interconnectedness, sustainability, and justice" and to unveil how art shapes the public's environmental attitudes and practices. ${ }^{27}$ His methodology lends itself to the scrutiny of CSR aesthetics in that it can help deconstruct its symbolism to unveil the missing narratives or issues that relate to environmental inequalities and damage. Going further, William Fox and T.J. Demos advocate artistic practices that, in themselves, critically interrogate and expose the cultural and institutional forces driving environmental

24 Allen Carlson, Aesthetics and the Environment: The Appreciation of Nature, Art and Architecture (New York: Routledge, 2000).

25 Yuriko Saito, Aesthetics of the Familiar: Everyday Life and World-Making (Oxford: Oxford University Press, 2017) at 1; Andrew Light \& JM Smith (eds), The Aesthetics of Everyday Life (New York: Columbia University Press, 2005).

26 G Böhme, The Aesthetics of Atmospheres (New York: Routledge, 2017); B Anderson, "Affective Atmosphere” (2009) 2 Emotion, Space and Society 77; S Grant, "Performing on Aesthetics of Atmosphere" (2013) 23:1 Aesthetics 12.

27 Alan C Braddock, "Ecocritical Art History" (2009) 23:2 American Art 24 at 26. 
degradation. ${ }^{28}$ The censure of corporate marketing and logos by anti-capitalist commentators, such as Naomi Klein, ${ }^{29}$ and Fredric Jameson's critique of the hyper-commodified character of "late capitalism," conveys similar sentiments. ${ }^{30}$ These perspectives provide a useful backdrop to this article's later discussion of the "counter-aesthetics" that challenge disingenuous corporate marketing. Together, they imply that a critical and sceptical perspective of CSR aesthetics is not something that the general public will likely possess without guidance from artists, environmental activists, and other dissenting stakeholders who can unmark green illusions and engage the public's imagination through humour, satire, irony, and other tactics.

Finally, the interface between law and aesthetics itself has relevance for our analysis of CSR aesthetics as the law may mediate the public's perception of business communications. Research on this interface has coalesced into three clusters of enquiry. ${ }^{31}$ First, one can consider how the law adjudicates aesthetic issues, such as in intellectual property law, public decency regulation, cultural heritage protection, and land use planning, with the focus commonly on how the law, as a word-centric discipline, interprets and incorporates visual and acoustic factors into legal doctrine. ${ }^{32}$ For instance, researchers have examined the codification of standards of "natural beauty" for environmental protection, such as through the delineation of landscape values to be safeguarded from "unsightly" wind turbines or other rural infrastructure. ${ }^{33}$ This scholarship has relevance here for understanding the challenges that consumer protection and trademark law have in evaluating the aesthetic dimensions of corporate marketing. Less relevant is a second cluster of research from the "law and literature" school, which conceptualizes the law as a performative language and examines what the law can learn from literature. ${ }^{34}$ Analysis of the use of poetic features in court judgments such as proverbs, similes, rhyme, and so forth, however, will shed little light on the governance of CSR aesthetics. ${ }^{35}$ However, by highlighting how written text itself can have aesthetic qualities, this scholarship is relevant for this article's analysis of the figurative discourse of CSR, which through metaphors and other literary devices has acquired a powerful hold on perceptions of corporate environmental practices. Third, some research has investigated the legal system itself as having aesthetic properties in its modes of legal reasoning, rituals, and symbols of authority such as courtroom architecture and judicial attire. ${ }^{36}$ By revealing how legal texts and institutions can have sensory and emotional significance, this approach has some utility for our enquiry into non-state actors in CSR governance. The

28 TJ Demos, Against the Anthropocene: Visual Culture and Environment Today (Berlin: Sternberg Press, 2017); William L Fox, "The Art of the Anthropocene" in J Newell, L Robin \& K Wehner, eds, Curating the Future: Museums,

Communities and Climate Change (London: Earthscan, 2017) 196.

29 Naomi Klein, No Logo: Taking Aim at the Brand Bullies (New York: Picador, 1998).

30 Fredric Jameson, Postmodernism, or, the Cultural Logic of Late Capitalism (Durham, NC: Duke University Press, 1991).

31 Desmond Manderson, Songs without Music: Aesthetic Dimensions of Law and Justice (Berkeley: University of California Press, 2000) at 28-36.

32 See Costas Douzinas \& Lynda Nead, eds, Law and the Image: The Authority of Art and the Aesthetics in Law (Chicago: University of Chicago Press, 1999).

33 Benjamin J Richardson, Emily Barritt \& Megan Bowman, “Beauty: A Lingua Franca for Environmental Law?” (2018) 8:1 Transnational Environmental Law 59

34 E.g. Ed Morgan, The Aesthetics of International Law (Toronto: University of Toronto Press, 2007); Adam Gearey, Law and Aesthetics (Oxford: Hart Publishing, 2001).

35 Dennis Kurzon, "Poetic Language and Court Opinions" in R Kevelson, ed, Law and Aesthetics (New York: Peter Lang, 1992) 281 at 295-297.

36 Manderson, supra note 31 at 30-31. 
artistic practices of culture jamming, as a form of market governance that challenges corporate authority, can be viewed through this lens. Its activities embody aesthetic properties associated with defacing billboards, hijacking corporate websites, and reconfiguring business logos. Culture jamming garners influence not as an abstract idea but, rather, as an expressive, aesthetic phenomenon that influences people's emotions, values, and practices.

To sum up then, the literature offers a variety of analytical and normative theories of aesthetic appreciation, but only those that can shed light on the purpose, impact, and control of CSR aesthetics will be useful for the subject matter of this article. We need to understand CSR aesthetics as more than consumer taste, as it relates also to expressions of business personality, discourse, and agenda as well as providing the ability to decipher how art and law can control or challenge dubious corporate marketing and branding. The following part examines the aesthetic of business corporations and the marketplace in which CSR is embedded, before turning to CSR specifically.

\section{CORPORATE AESTHETICS AND GREENWASHING}

\section{A. CSR Marketing}

The modern business corporation is an aesthetic phenomenon. You would not think so, however, by witnessing the generally austere rituals of shareholder meetings and boardroom deliberations. Their tedious formalities - from filing shareholder resolutions to listening to chief executive officer [CEO] speeches - belie the enlivened corporate identity projected to the wider world. That external persona is also much more than stylish corporate offices or boardrooms decorated with fine art ${ }^{37}$ it transpires through corporate logos, websites, colourful publicity documents, and ubiquitous product marketing. Philip Hancock, a leading researcher of business culture, finds that aesthetics permeates "virtually every activity" of corporate life. ${ }^{38}$ In their plea for Beautiful Corporations, Paul Dickinson and Neil Svensen argue that successful companies must offer "style, beauty, a positive attitude and pleasing experiences" for their staff and customers. ${ }^{39}$ Corporate aesthetics has also penetrated a variety of cultural spheres beyond the marketplace, including sports, arts, and leisure events, where business logos and marketing can sometimes have greater prominence than the activities supported. ${ }^{40}$

Disciplining employees to boost their productivity is one of the foremost purposes of corporate aesthetics. In British call centres, Catrina Alferoff and David Knights found that managers try to mask the drudgery through colourful decorations, party games, and dressing up themes ${ }^{41}$ Aesthetics also underpins a "regime of surveillance," such as "digital displays ... reminiscent of seaside or Christmas illuminations" that monitor call handling and sales results. ${ }^{42}$ The aestheticization of the workspace also strongly permeates the information technology industry, where vibrant colour schemes and swish offices project a

37 Although some edifices can be potent symbols of corporate values - notably, the Chrysler building in New York and the Bank of China tower in Hong Kong.

38 Hancock, supra note 9, at 52.

39 Paul Dickinson \& Neil Svensen, Beautiful Corporations: Corporate Style in Action (London: Prentice-Hall, 2000) at 3.

$40 \quad$ Klein, supra note 29.

41 Catrina Alferoff \& David Knights, "We're All Partying Here: Target and Games, or Targets as Games in Call Centre Management" in A Carr \& P Hancock, eds, Art and Aesthetics at Work (New York: Palgrave Macmillan, 2003) 70.

42 Ibid at $74-75,87$. 
"creative" atmosphere; Google's headquarters in Australia include "offices with picnic benches, fish tanks, local flora, the beach-themed Café Esky and a games room." 43 Music is also sometimes played, with some companies creating organizational theme songs to cultivate staff loyalty. ${ }^{44}$

Aesthetics has an even larger role in seducing consumers, with some major companies' advertising expenditures outstripping their costs in the physical production of goods. ${ }^{45}$ Our postmodern culture has "freed aesthetic experiences from the domain art, and made them more widely available to the masses," in which we now "consume on the basis of style, symbolism and fashion," explains Philip Hancock. ${ }^{46}$ In The Substance of Style, US cultural writer Virginia Postrel observes that "the look and feel of products will determine their success. Sensory, even subliminal, effects will be essential competitive tools." 47 She cites examples such as Apple's brightly coloured computers and Visa's designer-looking credit cards. ${ }^{48}$ The aestheticization of consumption extends to individuals' own bodies; in 2017, the global cosmetics market was worth US $\$ 532$ billion. ${ }^{49}$ Despite fiery feminist critiques such as Naomi Wolf’s The Beauty Myth, ${ }^{50}$ the industry flourishes thanks to ubiquitous fashion magazines, television advertising, and celebrity endorsements. ${ }^{51}$

Shopping itself has become an aesthetic ritual, and the places patronized by consumers offer distinctive aesthetic atmospheres. We have entered an "experience economy," explain Joseph Pine II and James Gilmour, where the consumer "buys an experience, [to] spend time enjoying a series of memorable events that a company stages - as in a theatrical play." "52 Such "memorable" experiences are not confined to amusement parks and glitzy casinos. "Entertainment restaurants" such as Hard Rock Café and Planet Hollywood bring diners into an orchestrated sensory milieu in which the décor, music, artwork, aromas and other features work in unison to convey a well-defined aesthetic theme. ${ }^{53}$ A coffee at Starbucks might evoke a similar experience; according to its former CEO, Howard Schultz, "every Starbucks store is carefully designed ... [t] he artwork, the music, the aromas, the surfaces all have to send the same

43 University of New South Wales Business School, "Workspace Design: Will Aesthetics Give Your Business the Edge" (5 October 2010), online: Business Think<www.businessthink.unsw.edu.au/Pages/Workspace-Design-Will-AestheticsGive-Your-Business-the-Edge.aspx $>$.

44 Nick Nissley, Steven Taylor \& Orville Butler, "The Power of Organizational Song: An Organizational Discourse and Aesthetic Expression of Organizational Culture" in Carr \& Hancock, supra note 41 at 93.

45 Trevor Norris, Consuming Schools: Commercialism and the End of Politics (Toronto: University of Toronto Press, 2011) at 6.

46 Philip Hancock, "Aestheticizing the World of Organization: Creating Beautiful Unique Things" in Carr \& Hancock, supra note 41 at $174,174-175$.

47 Virginia Postrel, The Substance of Style: How the Rise of Aesthetic Value Is Remaking Commerce, Culture, and Consciousness (New York: Harper, 2003) at 2.

48 See further on product aesthetics Robert Veryzer, "The Place of Product Design and Aesthetics in Consumer Research" (1995) 22 Advances in Consumer Research 641.

49 "Global Cosmetics Products Market Expected to Reach USD 805.61 Billion by 2023 - Industry Size \& Share Analysis," Reuters (13 March 2018), online: <www.reuters.com/brandfeatures/venture-capital/article?id=30351>.

50 Wolf, supra note 16.

51 Geoffrey Jones, Beauty Imagined: A History of the Global Beauty Industry (Oxford: Oxford University Press, 2010) at 278-290.

52 B Joseph Pine II \& James H Gilmore, The Experience Economy: Work Is Theatre and Every Business a Stage (Boston: Harvard Business School Press, 1999) at 2.

53 Ibid at 46. 
subliminal message as the flavor of the coffee." ${ }^{54}$ Shopping malls elevate these principles to a larger scale with piped music, perfumed spaces, and mood lighting to encourage shoppers to linger and spend. ${ }^{55}$ For consumers too lazy to leave home, they can watch one of the continuously streamed television stations devoted to shopping, such as the Shopping Channel and QVC.

These aesthetic attributes, especially for large multinational firms, coalesce into the brand that evokes the company's values and promotes cultivated associations with certain lifestyles and status. The importance of brands to business success is often quantified by the value of its "goodwill," and it enables strong-brand firms to earn super profits beyond that which flow just from their tangible assets such as property and machinery. According to Forbes, the value of the three most successful global business brands in 2018 were Apple (US \$182 billion), Google (US \$132 billion), and Microsoft (US \$104 billion), ${ }^{56}$ all companies active in media and communications where corporate aesthetics matters greatly. Although brand value is not generally itemized on a company's balance sheet, one study estimated it to be worth 74 percent of the market value of companies on the Standard and Poor's 500 Index. ${ }^{57}$ Strong brands benefit companies in two ways: first, consumers pay a premium for products that have brand recognition and, second, investors prefer shares of companies they trust, resulting in a premium to purchase them.

Aesthetics not only promotes consumerism, thereby burdening the environment, but companies also use aesthetic effects to "reassure" consumers of their environmental values in an effort to continue their financial success. These aesthetic effects are used not merely to promote business in obviously environmental-themed sectors, such as eco-tourism, ${ }^{58}$ but the alluring music and imagery in corporate marketing can also serve to bring credibility to claims about business practices masquerading as "zero emissions," "carbon neutral," or "sustainable." Disingenuous corporate communications can make the public complacent, especially in the absence of regulatory oversight to curb misleading statements.

It would require an encyclopaedia to catalogue the litany of corporate green washing, but some illustrative transgressions can convey common practices. ${ }^{59}$ The Fiji bottled water commercial clashes with the reality of plastic packaging, the carbon emissions from transporting the bottles internationally, and the landfill waste after their fleeting consumption. The Nissan Leaf commercial shows a polar bear ambling through the countryside until it meets a motorist about to get into his Nissan electric car, whereon it receives a comforting hug; the inference that the car can help motorists do their bit to curb fossil fuel use omits the various cognate environmental impacts (from car manufacturing to road construction). ${ }^{60}$ The labels on Dawn's antibacterial soap depict ducklings and seal pups with the assurance that "Dawn helps save wildlife," as it donates soap to wash animals after oil spills and funds rescue volunteers, but the product contains Triclosan, a toxic chemical that environmentalists want banned. In 1990, DuPont, a large

54 Quoted in Postrel, supra note 47 at 20.

55 Mikita Brottman, "The Last Stop of Desire: The Aesthetics of the Shopping Center" in Arnold Berleant \& Allen Carlson, eds, The Aesthetics of Human Environments (Peterborough: Broadview Press, 2007) at 119.

56 "The World's Most Valuable Brands," Forbes, online: <www.forbes.com/powerful-brands/list/3/\#tab:rank>.

57 Jonathan Knowles, "How How of Enterprise Value Is Intangible?" (8 March 2017), online: Linked in $<$ www.linkedin.com/pulse/how-much-enterprise-value-intangible-jonathan-knowles $>$.

58 See Adriana Campelo, Robert Aitken \& Juergen Gnoth, "Visual Rhetoric and Ethics in Marketing of Destinations" (2011) 50:1 Journal of Travel Research 3.

59 See the Greenwashing Index, online: <www.greenwashingindex.com $>$, from which some examples are drawn.

60 See film clip online: Youtube <www.youtube.com/watch?v=P5IJcysD18s $>$. 
US industrial and chemical company, unveiled its safer, double-hulled oil tankers with advertisements featuring seals and other marine life approvingly clapping their flippers or wings to Beethoven's "Ode to Joy." 61 As several of these examples show, CSR aesthetics garners their deceptive power by taking images or sounds out of their original context to spin a seductive new narrative.

Logos provide another potent aesthetic symbol of corporate eco-friendly pretences. In response to the criticism of its environmental practices, British Petroleum launched a massive rebranding effort in 2000 that included a new logo of a green-and-yellow sunflower, officially symbolizing the sun god of ancient Greece, and changed its name to BP with the tagline, "Beyond Petroleum." ${ }^{2}$ Yet this is the same company that was later responsible for the 2010 Deepwater Horizon oil spill and for whom fossil fuel sales still account for the vast majority of its revenue. In 2009, the fast-food chain McDonalds experimented with literally green washing its logo, by swapping the red backdrop of its famed golden arches for a comforting green shade. ${ }^{63}$ Sometimes, the mischief arises from a company exploiting the logo or label associated with an environmental certification system; class action lawsuits were taken against S.C. Johnson over its misleading Green list logo on some of its products that did not adhere to the standards implied by the green label ${ }^{64}$ Companies invest a lot in their logos because they know that consumers are more likely to recall a visual symbol than a written description. Relevantly, respected US entrepreneur Paul Hawken remarked that the average American can recognize 1,000 corporate logos but fewer than ten native plants in their locality. ${ }^{65}$

Corporate websites offer particularly accessible platforms for disseminating more complex narratives about business environmental credentials. The global agricultural chemicals supplier Monsanto has a website dominated by a photograph of a verdant field of crops illuminated by a brilliant sunrise. ${ }^{66}$ The Ford car manufacturer's website displays revolving images of its vehicles, mostly depicted in scenic backdrops such as rugged countryside and certainly without traffic jams or pollution. ${ }^{67}$ Kentucky Fried Chicken's homepage centres on a one-minute video clip of happy families being delivered the fingerlickin' chicken wings by Colonel Sanders himself, but there is no sight of the horrendous factory farms that supplied them. ${ }^{68}$ The website of British American Tobacco, the world's largest tobacco business, also has a pop-up video, which tells the "touching" stories of the farmers and others who work for "a progressive company that's proud of its heritage and excited about the future." ${ }^{69}$ Researchers who have examined numerous corporate websites have observed that any detailed information about CSR, such as the firm's sustainability reports, "can often be found only by burrowing through the obscure recesses of

\footnotetext{
61 Advertisement available online: Youtube $<$ www.youtube.com/watch?v=zJZFfeLRCJs $>$.

62 Don Pittis, "Remembering Back When BP Was Green, Like Its Ads Said," CBC News (3 June 2010), online: CBC <www.cbc.ca/news/canada/remembering-back-when-bp-was-green-like-its-ads-said-1.919998>.

63 "McDonalds's Rolling Out Green Logo in Europe," NBC News (23 November 2009).

64 Jonathan Bardelline, "SC Johnson Settles Lawsuit over Greenlist Logo," GreenBiz (8 July 2011), online: $<$ www.greenbiz.com/news/2011/07/08/sc-johnson-settles-lawsuits-over-greenwashing-greenlist-logo>.

65 Paul Hawken, The Ecology of Commerce (New York: HarperBusiness, 1993) at 214.

66 Monsanto, online: <https://monsanto.com>.

67 Ford, online: $<$ www.ford.com $>$.

68 Kentucky Fried Chicken, online: <www.kfc.com/videos/oB5GrmaxH8k>.

69 British American Tobacco, online: <www.bat.com $>$.
} 
corporate websites - available to the literati." ${ }^{70}$ It would appear that businesses are more interested in the aesthetics of CSR rather than giving their stakeholders meaningful, tangible information on which to closely scrutinize their efforts.

The foregoing discussion should be enough to convey the picture; aesthetics matters greatly to corporate identity and communication of their environmental practices and products. Consumers are bombarded with business aesthetics, from websites and television commercials to the presentation of shops and their wares. This does not mean that companies fail to provide other sources of information about their sustainability policies and eco-impacts, but technical reports require considerably more attention from consumers. Aesthetic practices matter precisely because of their power to viscerally communicate and seduce people in an information-saturated world.

\section{B. CSR Practices and Discourse}

While the communication and marketing of CSR obviously dwells within an aesthetic realm, many wrongly perceive that the underlying CSR practices reflect only technical expertise and managerial prowess, involving cost-benefit calculation, technological innovation, executive leadership, and skilful stakeholder negotiations. The field of CSR has several dimensions that an aesthetic lens can illuminate. At the outset, the very evolution of CSR responds partly to the heightened sensory reactions to environmental and social adversity. This is because corporate hubris tends to be most damaging to a company's reputation when it is dramatic, such as a devastating oil spill like the 2010 Deepwater Horizon catastrophe. ${ }^{71}$ Some companies' reluctance to disclose their environmental practices stems precisely from the fear of arousing or amplifying awareness of such environmental trauma. The plethora of corporate environmental policies, plans, and promises serves, at best, to prevent such unsightly impacts arising in the first place or, at worst, to deflect attention from those that inflict them.

Second, the making of CSR policies and plans can involve consultations with important stakeholders - notably, suppliers and local communities - and the negotiation of voluntary agreements. These processes can have aesthetic dimensions, such as the aesthetic atmosphere of forums convened for liaising with local communities. When an Australian mining company negotiates an Indigenous land use agreement with an Aboriginal community whose land it wishes to exploit, we must consider the relevance of where and how such an agreement is negotiated: in the community itself, with company officials meeting local tribal elders in a setting and forum they find comforting or in the company's austere headquarters in Sydney or Melbourne?72 The concept of "aesthetic atmospheres" noted earlier is helpful for evaluating how such considerations may impact on the negotiations,

Third, in actual business practices, aesthetic factors can influence the design of products or the delivery of services. A company might invest in green building standards for its headquarters in order to earn

70 Stephen Garnett, Kerstin Zander \& Michael Lawes, "A Simple Greenwash Detection Tip: Check What the Firm Puts on Its Homepage," The Conversation (11 November 2015), online: $<\mathrm{http}$ ://theconversation.com/a-simple-greenwashdetection-tip-check-what-the-firm-puts-on-its-homepage-50447>.

71 Earl Boebert \& James M Blossom, Deepwater Horizon: A Systems Analysis of the Macondo Disaster (Cambridge, MA: Harvard University Press, 2016).

72 Marcia Langton \& Lisa Palmer, "Modern Agreement Making and Indigenous People in Australia: Issues and Trends" (2003-2004) 8 Australian Indigenous Law Reporter 1. 
official certification of its CSR credentials - a highly overt and tangible aesthetic statement. ${ }^{73}$ A socially responsible business might design products that are durable, able to used time and again, and that maintain consumers' interest as aesthetically appealing, which keeps such products outside of the "ugly" waste streams longer. ${ }^{74}$ Some business sectors are directly engaged in nature aesthetics, as in the eco-tourism sector where everything from wildlife safaris to resort spas are designed from strong sensory experiences.

Most important, in my opinion, are the aesthetics of CSR language. A distinctive vocabulary permeates CSR codes of conduct, reports, agreements, business conferences, and media coverage, enriched by metaphors and other figurative language that help companies articulate a specific narrative for the public's assimilation. ${ }^{75}$ Manipulative linguistic devices are not unique to CSR; they pervade the business world at large. They include seductive slogans such as the "trickle down effect" (alluding to how the disproportionate wealth of the rich should bring prosperity for society generally) and the market's "invisible hand" (a metaphor about the supposed social benefits that flow from the efficiency of market forces in bringing supply and demand into equilibrium). This aestheticized language not only serves to render abstract economic ideas into a simple formula that the mass public can readily comprehend, but it also aims to influence mass opinion in politically significant ways such as decisions about how to govern markets and business.

A sample of key CSR jargon illustrates its seductive power. The phrase "triple bottom line" has become ubiquitous in CSR parlance, using the bottom-line metaphor from financial performance as a template for understanding the need for companies to perform along economic, social, and environmental metrics. The metaphor appears to have been coined by John Elkington, a co-founder of SustainAbility, a CSR business consultancy ${ }^{76}$ By drawing on a concept founded in core business practice, the triple bottom line implies rigour and objectivity. In practice, its application has been flawed for several reasons: difficulties in quantifying social and environmental performance into neat metrics analogous to financial accounting; businesses' latitude in how they seek to improve their sustainability performance; and the lack of transparency by businesses in communicating this performance.

Another seminal metaphor in CSR discourse is "natural capital," which depicts the natural world as performing functions similar to those of economic capital that require equal respect by business managers and policy-makers. The metaphor appears to have been coined in the 1970s and gained global currency with the publication of the book Natural Capitalism in $1999 .{ }^{77}$ This terminology has become a framework for companies to report on their environmental performance, making visible the value of the natural world to corporate balance sheets and social welfare and thereby creating incentives for business and governments to manage natural resources sustainably. The metaphor has also become formally incorporated into some CSR governance instruments - notably, the Natural Capital Declaration, which

73 International Living Future Institute, Living Building Challenge: 3.1 Standard, online: Living Future $<$ https://livingfuture.org/product/lbc-3-1-standard>.

74 Kristine H Harper, Aesthetic Sustainability: Product Design and Sustainable Usage (London: Earthscan, 2018).

75 See Helen Kopnina, "Metaphors of Nature and Development: Reflection on Critical Course of Sustainable Business" (2016) 22:4 Environmental Education Research 571.

76 John Elkington, "Enter the Triple Bottom Line" in A Henriques \& J Richardson, eds, The Triple Bottom Line: Does It All Add Up? (London: Earthscan, 2004) 1.

77 Paul Hawken, Amy Lovins \& Hunter Lovins, Natural Capitalism: Creating the Next Industrial Revolution (Boston: Little Brown and Company, 1999). 
was adopted in June 2012, an initiative of the financial sector for promoting social investing. ${ }^{78}$ As with the triple bottom line, the concept of natural capital is open-ended and does not in itself present a standardized, rigorous methodology for managing or reporting on the value of natural resources and ecosystem services. It also has deeper implications for how we relate to the natural world; Brian Coffey suggests that the metaphor provokes us to ask the wrong question, which should not be "what's the value of nature" - a narrow, commodified view of the biosphere - but, rather, "why is nature important" to our lives. ${ }^{79}$

Other important phrases in CSR discourse, and also in government policy-making, are the interrelated "circular economy" and "cradle to grave." They share the premise that the economy should functions within a closed loop system where no harmful waste is produced and where goods can be recycled and reused indefinitely. By embracing it, CSR-conscious companies should benefit financially by gaining competitive advantages and improving production efficiency, all the while supposedly saving the planet without the need for systemic reform to market systems. ${ }^{80}$ Like natural capital, the language of the circular economy and cradle to grave assists the business world in maintaining its preferred status quo.

In the realm of social investing - an important CSR niche - several bespoke literary devices have emerged. One is "slow money," which is tied to a movement of this name that advocates patient, longterm investing to support social justice and ecological sustainability. The movement is most visibly associated with American social entrepreneur Woody Tasch, whose bestseller Slow Money champions greater financial support for local food enterprises and organic farms ${ }^{81}$ Another recent addition to the lexicon of social investing that has significant traction in both the financial sector and mainstream media is "stranded assets," a metaphor that climate change will cause some financial assets to lose value or become liabilities before the end of their economic life. It is used principally in relation to fossil fuel industries such as coal mining, powerfully invoking the prospect of being marooned and helpless. ${ }^{82}$

Clearly, CSR discourse and practice draws on aesthetics to influence how society should conceive of corporations and their environmental activities and impacts. The aestheticized terminology of CSR, especially through metaphors and catchy slogans, does not merely serve to explain complex environmental phenomena or business practices in everyday idioms but also surreptitiously reframes contexts or issues that politically and economically benefit business interests. In essence, this terminology has the power to prescribe behaviour and governance.

\section{REGULATING GREEN ILLUSIONS}

78 Natural Capital Finance Alliance, online: <https://naturalcapital.finance>.

79 Brian Coffey, "Cents and Sensibility: Why It's Unwise to Put Dollar Figures on Nature," The Conversation (27

November 2015), online: $<$ https://theconversation.com/cents-and-sensibility-why-its-unwise-to-put-dollar-figures-onnature-49508>.

80 E.g. World Business Council for Sustainable Development and United Nations Environment Programme, Cleaner Production and Eco-Efficiency, Complementary Approaches to Sustainable Development (Geneva: World Business Council for Sustainable Development, 1998) at 3.

81 Woody Tasch, Slow Money: Investing as If Food, Farms and Fertility Mattered (Hartford, VT: Chelsea Green Publishing, 2008).

82 Dougal Shaw, "Climate Change and Cost: What Are 'Stranded Assets'?" BBC News (16 April 2015), online: $<$ www.bbc.com/news/av/business-32320825/climate-change-and-cost-what-are-stranded-assets $>$. 


\section{A. Fair Trading and Advertising Controls}

Regulation has not kept up with corporate green washing and environmental practice because of its failure to recognize and adapt to the growing aestheticized character of the business world and its CSR agenda. This part of the article examines how conventional legal tools for consumer protection and marketing address this challenge, while the following part extends this inquiry to trademarks and certifications. The aim is to highlight general patterns and problems with current regulations in regard to business aesthetics rather than to exhaustively analyze the vast body of regulations and case law.

In the name of intellectual property protection, governments have been more sensitive to safeguarding corporate aesthetics than curbing their misleading connotations. Copyright law in the United States, a leading shaper of global standards, has several times extended the duration of legal protection to authors' creations, largely to protect corporate interests such as the Walt Disney Company, which strenuously lobbied for such extensions and secured them in $1998 .{ }^{83}$ Trademarks also receive generous legal protection to safeguard corporate brands. Concomitantly, authorities in many jurisdictions have ceded more responsibility to businesses to manage their own environmental performance, such as through codes of conduct, advisory guidance, and contracts, thereby creating more opportunities for unscrupulous behaviour, given the mixed record of business self-regulation. ${ }^{84}$ Many of these voluntary CSR codes and standards contain expectations that participant companies will publicly disclose their environmental and social performance, but such expectations either relate to specific technical data, such as reporting greenhouse gas emissions, or are cast too broadly without the means to hold companies measurably accountable. ${ }^{85}$ A 2010 international study conducted by TerraChoice, an environmental marketing firm, found that about 95 percent of the seemingly pro-environmental products that it reviewed were tainted by some form of green washing. ${ }^{86}$ Worryingly, studies commissioned in 2009 by the US Federal Trade Commission showed that a product's environmental reputation influences the purchasing decisions of a majority of consumers. ${ }^{87}$ In other words, green illusions are pervasive and require legal oversight.

Regulations governing fair trading, trademarks, and investor protection are the main legal bulwark against green washing. Common law remedies in contract and tort law are also available in some jurisdictions for aggrieved consumers or investors, but because of limitations in their scope and the costly burden placed on litigants, government regulators now assume primary responsibility for supervising corporate communications. A few examples will illustrate the most prevalent governance approaches around the world. Fair-trading regulation serves the policy goals of helping consumers make informed purchasing decisions and assisting businesses by promoting a level playing field in the market. Regulations target false or misleading advertising that is likely to influence consumers' decisions, covering all forms of business communications, including product packaging, websites, television, and

83 Steve Svhlackman, "How Mickey Mouse Keeps Changing Copyright Law," Art Law Journal (15 February 2014), online: $<$ https://alj.orangenius.com/mickey-mouse-keeps-changing-copyright-law $>$.

84 Virginia Haufler, A Public Role for the Private Sector: Industry Self-regulation in a Global Economy (Washington, DC: Carnegie Endowment for International Peace, 2001) at 31-52; R Gibson, ed, Voluntary Initiatives: The New Politics of Corporate Greening (Peterborough: Broadview Press, 1999).

85 See e.g. Global Reporting Initiative, online: <www.globalreporting.org $>$.

86 TerraChoice, The Sins of Greenwashing: Home and Family Edition (2010) at 6, online: $<$ http://sinsofgreenwashing.com/index35c6.pdf $>$.

87 Federal Trade Commission (FTC), Environmental Marketing Consumer Perception Study (Washington, DC: FTC, 2009). 
radio. Both active statements and omissions can amount to deceptive communications. For instance, Australia's Competition and Consumer Act 2010 makes it "illegal for a business to make statements that are incorrect or likely to create a false impression" and "when assessing whether conduct is likely to mislead or deceive," the regulator considers "the overall impression" created by the impugned conduct. ${ }^{88}$ Since these controls apply regardless of the medium of communication, they could capture some of the aesthetic expressions canvassed in the previous section of this article. The European Union's [EU] relevant directive defines "misleading advertising" as "a representation in any form" that "deceives or is likely to deceive" and "is likely to affect [consumers'] economic behaviour or which, for those reasons, injures or is likely to injure a competitor." $" 89$ The US Federal Trade Commission works within a comparable regulatory framework under the Federal Trade Commission $A c t^{90}$ and has advised that it "looks especially closely at advertising claims that can affect consumers' health or their pocketbooks - claims about food, over-the-counter drugs, dietary supplements, alcohol, and tobacco and on conduct related to high-tech products and the Internet." 91 Additional standards are sometimes imposed on the product packaging. Canada's Consumer Packaging and Labelling Act "prohibits the sale, importation or advertisement of a pre-packaged product that has a label applied to it that contains false or misleading representations relating to or reasonably regarded as relating to that product." ${ }^{\text {92 }}$ Advertising controls in some countries are also articulated through codes propagated jointly by government and industry, such as Great Britain's Advertising Standards Authority's [ASA] codes ${ }^{93}$ and Canada's Code of Advertising Standards,${ }^{94}$ which restrict certain advertising conduct and provide for receiving complaints from the public. ${ }^{95}$

Fair-trading regulation has limitations for addressing the deceptive aesthetics of CSR. Several important considerations apply. First, absent positive disclosure obligations, such as divulging on packaging the ingredients in cosmetics or foodstuffs or reporting on greenhouse gas emissions, such regulations serve only to control false or misleading communications. In most jurisdictions, companies are not generally obliged to report on their overall sustainability performance. Yet when companies choose to make aestheticized claims about their CSR credentials, they may be caught by fair-trading controls. Second, although deceptive advertising controls extend to implied representations, such as images of beautiful scenery in product marketing, seasoned experts have observed that "implied claims are more difficult to challenge because their meaning is not always apparent or indisputable." 96 Misleading advertising law applies from a "word-centric" model that privileges written text over the audio-visual

88 Australian Competition and Consumer Commission, "False or Misleading Statements," online:

$<$ www.accc.gov.au/business/advertising-promoting-your-business/false-or-misleading-statements>. Competition and Consumer Law 2010 (Cth), s 18. Emphasis in original.

89 EC Directive 2006/114 Concerning Misleading and Comparative Advertising and Repealing Council Directive 84/450/EEC, [2006] OJ L376 at 23, art 2(a)(b).

9015 USC ss $41-58$, as amended.

91 FTC, "Truth in Advertising," online: <www.ftc.gov/news-events/media-resources/truth-advertising $>$.

92 Consumer Packaging and Labelling Act, RSC 1985, c C-38, s 7(1).

93 ASA, online: <www.asa.org.uk/codes-and-rulings/advertising-codes.html>.

94 Ad Standards, online: $<$ https://adstandards.ca/code>.

95 Debra Harker, "Achieving Acceptable Advertising: An Analysis of Advertising Regulation in Five Countries" (1998) 15:2 International Marketing Review 101.

96 James P Nehf, "Misleading and Unfair Advertising" in G Howells, I Ramsay \& T Wilhelmsson, eds, Handbook of Research on International Consumer Law (Cheltenham, UK: Edward Elgar, 2018) 90 at 92. 
dimensions of marketing and branding. ${ }^{97}$ Where companies have been successfully prosecuted for misleading advertising where images are involved, it is commonly because of the effect on consumers of the combination of imagery and words, as when the Australian Competition and Consumer Commission successfully sued Heinz for misleading claims in its packaging about the nutritional benefit of its children's food. ${ }^{98}$ Some companies' artistic advertisements, however, make no express claims at all, instead insinuating an aesthetic "atmosphere" from the music and imagery that influence consumers; one example is the clothes retailer The Gap's commercial "Khaki Swing," which was issued in 1999. ${ }^{99}$

Two other issues are also relevant. One is that regulation lacks uniform or clear definitions for many commonly used terms associated with corporate brands and products such as "cruelty free," "natural," or "climate friendly," and, thus, such figurative language or image-based representation of such ideals in corporate communications is even harder to control. Finally, consumer protection generally only applies where consumers are being reasonable in their interpretation of corporate marketing, and, thus, vulnerable consumers who are too trusting and uncritical may not be protected. ${ }^{100}$ Deceptive disclosures may incur both civil and criminal sanctions, as levied, for instance, by Canada's Competition Act $2002^{101}$ on businesses that "knowingly or recklessly make a representation to the public that is false or misleading in a material respect" and without the necessity proving that consumers have relied on such statements or personally suffered damage. Misleading environmental claims occasionally result in such sanctions. To illustrate, the Australian power retailer Momentum Energy was fined AUS $\$ 50,000$ by the Australian Competition and Consumer Commission after it determined that the firm's electricity supplied to customers was not 100 percent renewable or generated from "thin air and fresh water," as it had boasted. ${ }^{102}$ In 2013, two New Zealand plastic bag manufacturers were fined NZ \$30,000 and NZ \$60,000 respectively for misleading the public with their marketing about the biodegradability and eco-friendliness of their disposable plastic rubbish bags; investigations by the Commerce Commission found that the bags would not in fact biodegrade in typical landfill conditions. ${ }^{103}$ British authorities banned BMW from falsely advertising that its i3 model was a zero-emission "clean car."104

Although severe penalties are occasionally imposed for deceptive conduct, such as the penalty recently levelled against Volkswagen for falsely claiming low emissions from its diesel car ${ }^{105}$ and manipulating the emission test results, regulators take a conciliatory approach in most cases that aims to merely stop the offending behaviour and educate businesses to do better. ${ }^{106}$ Newspapers often report that companies

97 Rebecca Tushnet, "Looking at the Lanham Act: Images in Trademark and Advertising Law" (2011) 48:4 Houston LR 861 at 862.

98 Australian Competition and Consumer Commission v HJ Heinz Company Australia Limited, [2018] FCA 360.

99 "Khaki Swing," online: Youtube <www.youtube.com/watch?v=knW1hGwmEXQ>.

100 Nehf, supra note 96 at 93.

101 RSC 1985, c C-34, s 52(1).

102 Richard Baines, "Momentum Energy Ads Falsely Claimed Power Generated 'From Thin Air and Fresh Water', ACCC Rules," ABC News (21 April 2016), online: <www.abc.net.au/news/2016-04-21>.

103 "Rubbish Bag Maker Fined \$60k over Environmental Claims," New Zealand Herald (19 November 2013), online: $<$ www.nzherald.co.nz/business/news/article.cfm?c_id=3\&objectid=11159622>.

104 Josie Clark, "BMW Electric Car Advert Banned for 'Misleading' Zero-emissions Environmental Claims," The Independent (6 December 2017).

105 "Diesel Emissions Scandal: VW Fined $€ 1$ bn by German Prosecutors," BBC News (13 June 2018), online: $<$ www.bbc.com/news/business-44474781>.

106 Nehf, supra note 96 at 107-109. 
receive a mere "slap on the wrists" for misleading advertising, which typically involves a regulator's direction to cease such conduct. ${ }^{107}$

\section{B. Trademarks and Certifications}

While the aesthetics of corporate communications can fall within the purview of fair-trading regulations, which focus on the overall impression of conduct in determining whether it is misleading, such regulation tends to be helpful primarily for sanctioning misleading advertisements about products or services rather than tackling the brand identity of a company that may itself contribute to green washing. The aesthetic character of a company's logo, website, and other expressive elements of its brand tend to be difficult to verify as being deceptive compared to product advertising since their connotations about environmental quality tend to be far more subtle and open to interpretation, in addition to being less concretely tied to the retailing of specific products or services.

One legal tool that can address aspects of corporate brand identity is trademark law. Trademarks are a form of symbolic capital that provides an "aesthetic monopoly" for their holders in the market. ${ }^{108}$ Many businesses rely on distinctive logos or other trademarks to attract consumers since they "reduce transaction costs by giving consumers concise and reliable ways to identify goods and services in the marketplace." 109 Trademarks are intimately tied up in corporate brands and may even serve to represent the distinctive environmental characteristics and qualities of businesses and their products. In order to attain these economic advantages, trademarks need legal protection, especially to prevent consumers from being misled by rival businesses passing off similar logos.

Like prohibitions on misleading advertising, trademark registration procedures bar the registration of deceptive marks. In recent years, trademark regulators have received many applications for trademark registrations with environmental connotations, notably marks that include words such as "green," "eco-," "sustainable," "natural," and other environmental buzzwords. ${ }^{110}$ Between 2004 and 2012, there were 2,267 trademark applications in Australia alone using such language. ${ }^{111}$ Aesthetic symbols implying such terms that may also be part of a trademark application include a leaf, tree, animal, or Earth. Some trademark offices are becoming more vigilant with such applications. In 2013, the US Patent and Trademark Office (which is empowered under the Lanham (Trademark) Act 1946 to bar the registration of deceptive trademarks), ${ }^{12}$ did so in regard to an application to register the trademark "Green Seal" for adhesive tape because it was considered to falsely and materially indicate that the applicant's goods are eco-friendly. ${ }^{113}$ Trademarks may also factor into misleading advertising controls; the US Federal Trade Commission has

107 E.g. Carly Page, "Talktalk Gets Its Wrists Slapped by the ASA for 'Misleading' Broadband Ads," The Inquirer (9 July 2014); Mark Russell, "Slap on Wrist for Power Balance," Sydney Morning Herald (21 November 2010).

108 Fritz W Haug, Critique of Commodity Aesthetics: Appearance, Sexuality, and Advertising in Capitalist Society (Minneapolis: University of Minnesota Press, 1982) at 41.

109 Aaron Perzanowski, "Unbranding, Confusion and Deception" (2010) 24:1 Harvard JL \& Tech 1 at 18.

110 "Eco Trademarks Made Big Gains in 2007," Greenbiz.com (28 April 2008), online: $<$ www.greenbiz.com/news/2008/04/28/eco-trademarks-made-big-gains-2007>.

111 Data cited in Rosanna Ryan, "Academic Sets Sights on Eco-label Loopholes," ABC News (9 February 2012), online: $<$ www.abc.net.au/news/2012-02-08/academic-sets-sights-on-eco-label-loopholes/3818746>.

112 Pub L 79-489, 60 Stat 427, s 2(a).

113 Interestingly, but immaterial to the ruling, the applicant had not claimed that its products are eco-friendly but, rather, that the "Green Seal" mark was merely one of several colour-coded adhesive tapes it sold. 
also warned that the use of corporate logos by affiliates of a company could result in unlawful deceptive conduct if consumers are misled about whether an affiliated business in a corporate group in fact adheres to the same policies and practices of the principal company. ${ }^{114}$

The law can also use corporate logos to help "name and shame" businesses that violate the law, including environmental regulations. This can be done when companies are obliged to place public notices in the media disclosing their violations, with the notices displaying the offending company's logo prominently to ensure audiences will readily identity the culprit. This sanction has been applied in some Australian prosecutions of corporate polluters. ${ }^{115}$ A related legal mechanism for protecting business goods is the geographical indication, taking the form of a name or sign, which is sometimes displayed as a visual logo, to use on certain products that correspond to a particular place of origin, such as a town or region. The geographical indication (sometimes also known as "appellations of origin") serves to designate product quality and highlight brand identity and is often associated with food, such as French champagne, and specialist manufactured wares, such as Swiss watches. They benefit producers by increasing their market recognition and ability to command premium prices. In an effort to harmonize countries' practices, the 1958 Lisbon Agreement for the Protection of Appellations of Origin and Their International Registration lays down provisions for what qualifies as geographical indicators and establishes a register of such indicators, ${ }^{116}$ while the 1994 Agreement on Trade-Related Aspects of Intellectual Property Rights obliges state parties to prevent the public being misled as to the geographical origin of goods. ${ }^{117}$ Whereas a trademark informs consumers about a good's commercial source, a geographical indication can distinguish the good itself and, in particular, highlight its environmental qualities such as food grown organically in a particular region.

Another governance control is official guidelines for companies engaged in environmental marketing to promote clear, accurate, and substantiated claims. The International Chamber of Commerce and the International Standards Organization have issued environmental marketing codes, which have influenced guidelines adopted in many countries. ${ }^{118}$ The US Federal Trade Commission has published "Green Guides" in 1992 and 2012 to assist businesses marketing their environmental credentials to avoid misleading advertising accusations or lawsuits. ${ }^{119}$ The governing principles of the Green Guides, which are stated to apply not merely to explicit statements but also to claims "by implication, through ... symbols, logos,"120 are that businesses should: (1) make "clear, prominent, and understandable" statements; (2) identify what products or services the claims apply to; (3) do not "overstate ... an environmental attribute or benefit"; and (4) substantiate the basis to any comparative claim. ${ }^{121}$ The combination of text and images in marketing can amount to a claim of an environmental benefit, as

114 FTC, Competition and Consumer Protection Perspectives on Electric Power Regulatory Reform (Washington, DC: FTC, 2000) at s VIII.

115 Henry Jackson, "Victorian Environment Protection Authority Prosecution Update, July 2002 - April 2003” (2003) 2

National Environmental Law Review 27.

116 As revised in 1967, 923 UNTS 205.

117 1994, 33 ILM 81 (1994), art 22.

118 Worawan Y Ongkrutraksa, "Green Marketing and Advertising” in SK May, G Cheney \& J Roper, eds, The Debate over Corporate Social Responsibility (Oxford: Oxford University Press, 2007) 365 at 368-369.

119 FTC, "Green Guides," online: <www.ftc.gov/news-events/media-resources/truth-advertising/green-guides>.

120 Code of Federal Regulations, Part 260: Guides for the Use of Environmental Marketing Claims, s 260.1(c).

121 Ibid, s 260.3 . 
illustrated by the following example in the Green Guides: "A marketer's advertisement features a picture of a laser printer in a bird's nest balancing on a tree branch, surrounded by a dense forest. In green type, the marketer states, 'Buy our printer. Make a change." 122 The Green Guides explain: "[A]lthough this advertisement does not expressly claim that the product has environmental benefits, the featured images, in combination with 'buy our printer, make a change,' likely convey that the product has far-reaching environmental benefits," which the guides explain is likely to be deceptive in the absence of collateral evidence.

Specialist guidance has also been issued by authorities on particular environmental issues such as climate change. New Zealand's Commerce Commission has produced guidelines on marketing that relates to climate change issues, and it cautions businesses against making carbon-neutral or low-carbon claims "indiscriminately," and they ought to provide "a clear statement about which elements of the product lifecycle or your business activities have been offset." 123 Such guidance may help to control formal statements from companies about their climate change-related performance, but it says nothing about how visual, symbolic, or acoustic representation of such issues should be portrayed.

Recognizing the power of aesthetic representation of corporate practice, some governments have turned to the same strategy to control misleading advertising by introducing their own visual symbols of proenvironmental criteria. The oldest example is Germany's "Blue Angel" program, created in 1977 on the initiative of the German government to allow for eco-friendly products and services to be labelled and marketed with an easily identifiable label. ${ }^{124}$ Certified products and services, of which there are now some 12,000, can display the logo of the Blue Angel. Other examples of government-sponsored eco-labels include the Canadian Environmental Choice Program, the Nordic Swan, and the EU's Flower eco-label. The US Department of Agriculture (USDA) also certifies organic food producers, which can market the USDA organic logo. ${ }^{125}$ Some of these certification schemes are now administered by independent organizations in the private sector. The LEED ${ }^{\circledR}$ mark is one such example of an esteemed certification trademark, advertised to signify buildings of high energy efficiency and other sustainability criteria. Other prominent private sector, eco-certification examples include Carbonfree and Fair Trade. ${ }^{126}$ However, some researchers doubt the impact of these aesthetic symbols of environmental quality on consumer behaviour since the labels do not in themselves question the very necessity of some consumption: "[I]n some circumstances the most environmentally sustainable option is no purchase at all." 127 This suggests that if aesthetics is to have a wider role in tackling consumerism, they need to go further in promoting anti-consumer behaviour, an issue considered later in this article.

In securities regulation, another legal tool, misleading communications generally hinge on whether the information is "financially material" and would likely influence an investor's dealings with the company

122 Ibid, s 260.4.

123 Commerce Commission, Guidelines for Carbon Claims: Fair Trading Act 1986 (Wellington: Commerce Commission, July 2009) at 5.

124 See "Blue Angel: The German Ecolabel," online: Blue Angel <www.blauer-engel.de/en>.

125 US Department of Agriculture, "Organic Seal," online: USDA <www.ams.usda.gov/rules-regulations/organic/organicseal>.

126 See "Reduce Your Product's Carbon Footprint with Carbonfree Certification," online: Carbonfund $<$ https://carbonfund.org/product-certification $>$; Fairtrade $<$ http://fairtrade.com.au $>$.

127 Ralph E Horne, "Limits to Labels: The Role of Eco-labels in the Assessment of Product Sustainability and Routes to Sustainable Consumption" (2009) 33 International Journal of Consumer Studies 175 at 181. 
such as to buy its stock. A finding of misleading information rests heavily on the substantive content of the verbal or written communications made by the company's managers. Under Australia's Corporations Act 2001, to illustrate a common legal approach, the disclosure standards focus on financial information given to shareholders, ${ }^{128}$ and a company's environmental performance is only reported with regard to "any particular and significant environmental regulation." ${ }^{29}$ More expansive is the EU's non-financial reporting directive that requires large companies to publish reports periodically on the environmental and social impacts of their activities. ${ }^{130}$ Yet neither of these approaches is likely to have any direct relevance to the aesthetic attributes of corporate communications; their focus is the formal written reporting of financial and non-financial data.

Governance gaps in controlling the aesthetics of corporate communications are not substantively filled by private law rights and remedies. Common law rules that respond to misleading corporate communications are available under tort and contract law. ${ }^{131}$ These remedies can be useful to aggrieved consumers or investors where regulators fail to provide relief. Yet they have many drawbacks. Consumers cannot easily succeed with the tort of injurious falsehood since they must demonstrate that the companies have acted maliciously when making a deceptive advertisement. And because of privity of contract, consumers also have had difficulty benefiting from contractual remedies against retailers where products do not match the quality promised in advertisements made by the manufacturers. ${ }^{132}$ Also, in misrepresentation cases, individual consumers typically only suffer minor economic losses from purchasing a product, unless they suffer physical injuries (for example, from a cosmetic containing carcinogenic ingredients). Litigation itself is an expensive and risky proposition, although consumers might cooperate through class actions, which can also overcome the difficulty of proving sufficient personal losses.

To briefly sum up thus far, fraudulent or deceptive environmental claims are amplified by corporate aesthetics embedded in trademarks, websites, product packaging, and advertisements. Current laws regulating advertisements, trademarks, and investor protection provide the principal means of governing their aesthetic properties and content. They tend to capture only the most serious or overt abuses, require considerable resources to prosecute, and generally fail to recognize the ubiquitous and subtle permeations of corporate aesthetics that contribute to ecologically damaging consumerism. Consumption itself is completely outside the scope of these legal controls but may be regulated through other means, such as in waste control or recycling standards. Without adequate legal controls over the aesthetics of consumerism and corporate identity, businesses that actually adhere to high environmental standards may not benefit from their efforts since consumers or investors are unable to easily identify the genuinely environmentally responsible firms. The advent of environmental certification schemes, however, can help genuinely proenvironmental businesses through aesthetic symbols that give consumers verification of sustainability standards. But they also do not in themselves take any stance against pervasive consumerism and ironically

128 Corporations Act 2001 (Cth), Part 2M.3 on Financial Reporting.

129 Ibid., s 299(1)(f).

130 EU Directive 2014/95 Amending Directive 2013/34/EU as Regards Disclosure of Non-Financial and Diversity Information by Certain Large Undertakings and Groups, [2014] OJ L330.

131 John Goldring et al, Consumer Protection Law (Sydney: Federation Press, 1998) at 96-99 (discussing Australian common law).

132 See Singer $v$ Schering-Plough Canada Inc, [2010] ONSC 1737, where a company made misleading statements in its advertisements and product labelling about the protection its sunscreens offered against ultraviolet light. 
may even encourage it. The next part of this article examines how artists and collaborating social and environmental activist groups can help to fill this governance void by making businesses more accountable for their green illusions.

\section{THE ARTS AND COUNTER-AESTHETICS}

\section{A. Unmasking Green Illusions}

Confronting deceptive CSR aesthetics and the broader consumer economy that degrades the planet requires more than the foregoing regulatory regimes. While the aestheticized marketing and branding of consumerism cannot easily be rolled back, environmentalists can at least intervene to instil subversive messages that educate the public where regulators have failed. I call this stance "counter-aesthetics." Led by critical artists, partnering with environmental and community groups, it supplements rather than replaces government regulation as a form of market governance and, by shaping public opinion, may in turn promote stronger laws to address the underlying drivers of environmental decline such as carbon emissions. Counter-aesthetic strategies thus offer the means of both governing CSR directly and leveraging statutory reform.

Counter environmental aesthetics depend heavily on the creative arts to engage the public. The arts "can play a central transformative role," believes critic T.J. Demos, in leveraging "creative perceptional and philosophical shifts" that challenge the "destructive traditions of colonizing nature." 133 In his book Slow Violence, environmental humanities scholar Rob Nixon encourages artists to deploy "their imaginative ability and worldly ardour to help amplify the media-marginalized causes of the environmentally dispossessed." ${ }^{134}$ Concurring, Timothy Morton champions the arts for their power to help us reimagine our place in nature for a better environmental future. ${ }^{135}$ Morton sees the arts having a special role to help people perceive and understand environmental impacts that they do not directly experience. Such impacts, including global warming, are what Morton calls "hyper-objects" because they manifest over temporal and spatial scales that dwarf human perception. ${ }^{136}$ Where we cannot readily perceive environmental changes and impacts, artists have a special educative role that can leverage political and legal change.

The emotional and behavioural impacts of art is subject to growing empirical validation, including research on the specific pathways by which the arts may influence environmental attitudes and practices. ${ }^{137}$ One pathway is the communication of information represented in art works about environmental impacts, causes, and solutions. Art can convey such information in interesting and accessible ways that excite or intrigue audiences in a manner that cold intellectual representation of the issues in an academic journal does not. Rob Rosenthal and Richard Flacks suggest that art, including

133 TJ Demos, Decolonizing Nature: Contemporary Art and the Politics of Ecology (Berlin: Sternberg Press, 2016) at 19.

134 Robert Nixon, Slow Violence and the Environmentalism of the Poor (Boston: Harvard University Press, 2011) at 5.

135 Timothy Morton, Ecology without Nature: Rethinking Environmental Aesthetics (Boston: Harvard University Press, 2007).

136 Timothy Morton, Hyperobjects: Philosophy and Ecology after the End of the World (Minneapolis: University of Minnesota Press, 2013).

137 This paragraph draws partially on David J Curtis, Nick Reid \& Ian Reeve, "Towards Ecological Sustainability: Observations on the Role of the Arts" (2014) 7:1 Surveys and Perspectives Integrating Environment and Society, online: OpenEdition $<\mathrm{https} / /$ journals.openedition.org/sapiens/1655>. 
music, can help in "framing" ideas for the public that may reinforce or challenge prevailing assumptions. ${ }^{138}$ Second, art can be morally persuasive by creating empathy or compassion for the issues it addresses. A musical performance that contains a message about the dangers of climate change, for instance, may emotionally stir listeners in a novel way. The arts can also be used in overtly political guises to challenge government or corporate behaviour, including dubious CSR practices. Susanne Moser explores the power of the arts in climate change communications, fostering changes in social norms, motivating the public to act, and conveying the urgency of the challenges. ${ }^{139}$

One principal tactic of politically engaged art that directly challenges dubious CSR aesthetics and big name brands is known variously as "culture jamming," "ad busting," or "guerrilla art." 140 Drawing on the traditions of street art and media pranks, ${ }^{141}$ and the growing importance of taking art out of galleries and into public spaces, ${ }^{142}$ these actions typically involve artists hijacking billboards, reconfiguring logos, and parodying advertisements to radically subvert their messages. The art typically involves colourful, figurative, sculptural, and performative elements that are collectively authored without official authorizations. What makes this cultural sabotage so striking is that it "makes use of a corporation's own method of communication to send a message starkly at odds with the intended one."143 And the corporations typically foot the bill for the subversion as they are paying for the advertising space.

Crucial to such counter-aesthetics is the reclaiming of public spaces, such as town squares, sidewalks, bus stops, and civic buildings, which have succumbed to ubiquitous corporate marketing. Such creative activism has been theorized by commentators such as Eleftheria Lekakis as being reflective of a growing "political consumerism" in which political values and acts are transferred to the marketplace "to resist and reuse the logic of appropriation." 144 Since many public issues and social voices are marginalized by the dominance of market values and commercial communication, activists have had to turn to the market itself as a platform to express their grievances. Political consumerism has become particularly relevant to environmental activism because it seeks to expose the role of the market and rampant consumerism as drivers of ecologically unsustainable practices. ${ }^{145}$ Unlike other forms of political consumerism such as consumer and investor boycotts (for example, the fossil fuels divestment campaign), culture jamming uses artistic creativity to make transparent the environmental damages or the social suffering associated with a product or company.

Culture jamming is associated with practices of recent decades, but popular culture has a long history of being a site for expressing political dissent. Vince Carducci cites historic examples ranging from

138 Rob Rosenthal \& Richard Flacks, Playing for Change: Music and Musicians in the Service of Social Movements (London: Routledge, 2010).

139 Susanne Moser, "Communicating Climate Change: History, Challenges, Process and Future Directions" (2010) 1:1 Wiley Interdisciplinary Reviews: Climate Change 31.

140 Klein, supra note 29 at 279-330; Marilyn DeLaure \& Moritz Fink, eds, Culture Jamming: Activism and the Art of Cultural Resistance (New York: New York University Press).

141 See Nicholas Ganz, Graffiti World: Street Art from Five Continents (New York: Harry N Abrahams, 2004).

142 Julia Lossau \& Quentin Stevens, eds, The Uses of Art in Public Space (London: Routledge, 2015).

143 Margaret Kohn, Brave New Neighborhoods: The Privatization of Public Space (New York: London, 2004) at 167.

144 Elefteria J Lekakis, "Culture Jamming and Brandalism for the Environment: The Logic of Apropriation” (2017) 15:4 Popular Communication: The International Journal of Media and Culture 311 at 312.

145 Juliet B Schor, "Towards a New Politics of Consumption" in JB Schor \& DB Holt, eds, The Consumer Society Reader (New York: New Press, 2000) 446. 
China's Han Dynasty (202 BCE - $220 \mathrm{CE}$ ) to seventeenth-century Europe where songs, theatre, and cartoons expressed parody and satire against state power. ${ }^{146}$ The Dada movement that arose in Europe in the early twentieth century used art to protest against bourgeois nationalist and colonialist ideologies. ${ }^{147}$ The first pioneer of culture jamming against the corporate world is unconfirmed, but it may have been the Australian BUGA UP activists (short for Billboard Utilising Graffitists against Unhealthy Promotions), who began to cleverly deface billboards promoting tobacco and alcohol in the late 1970s. ${ }^{148}$

These and other tactics are now widely availed in counter environmental aesthetics. In the wake of the 1989 Valdez oil spill caused by an Exxon Corporation tanker, the Billboard Liberation Front re-messaged two towering billboards in San Francisco to state "Shit Happens. New Exxon." 149 Thousands of commuters saw them. The US-based Earth First, known for its particularly radical stunts, has cut down unsightly billboards that promote consumption or defaced them by inscribing pro-environmental messages. The culture-jamming duo Yes Men have been particularly notorious, specializing in the impersonation of business and government figures to criticize their behaviours and creating attentiongrabbing humour from these hoaxes. ${ }^{150}$ One famous example was staged on the twentieth anniversary of the Bhopal disaster in December 2004, where the Yes Men impersonated a Dow Jones executive interviewed on the British Broadcasting Corporation $[\mathrm{BBC}]$ to announce that it fully accepted responsibility and would pay for the cleanup of the contaminated Bhopal site and provide health care for the thousands of victims. ${ }^{151}$ The activist Greenwash Guerrillas, which specializes in street theatre and performance art, ${ }^{152}$ has targeted climate polluters; it participated in the 2010 protests outside London's National Portrait Gallery and Tate Gallery to highlight public opposition to BP's sponsorship of the arts. ${ }^{153}$ That campaign eventually had some success, with BP ending some of its sponsorship in 2017. ${ }^{154}$ At the 2015 Paris Summit on Climate Change, one irreverent group called Brandalism placed 600 posters around city bus stops mocking some big businesses, again targeting Exxon, for sponsoring the conference. ${ }^{155}$ Brandalism is particularly novel because, explains Lekakis, "it directly links the advertising industry to climate change and it calls for a debate on the ethics of advertising as a key battlefield over cultural meaning and environmental sustainability."156

146 Vince Carducci, "Culture Jamming: A Sociological Perspective" (2006) 6:1 Journal of Consumer Culture 116 at 130.

147 Theresa Papanikolas, Anarchism and the Advent of Paris Dada (Abingdon, UK: Ashgate, 2010).

148 Milissa Deitz, "Cut and Paste: Australia's Original Culture Jammers, BUGA UP" (2017) 11:2 Global Media Journal, online: Global Media Journal <www.hca.westernsydney.edu.au/gmjau/?p=816>.

149 "Shit Happens," press release (August 1989), online: Billboard Liberation Front $<$ http://billboardliberation.com/shit.html $>$.

150 Jacques Servin, "The Yes Men" in R Martin (ed), The Routledge Companion to Art and Politics (London: Routledge, 2015) 194 at 197.

151 The BBC interview is online: Youtube <www.youtube.com/watch?v=LiWlvBro9el>.

152 Greenwash Guerillas, online: <https://greenwashguerrillas.wordpress.com/about $>$.

153 John Vidal \& Owen Bowcott, "Galleries and Museums Face Summer of Protest over BP Arts Sponsorship," The Guardian (25 June 2010), online: <www.theguardian.com/environment/2010/jun/24/galleries-museums-summer-protestbp-arts-sponsorship>.

154 Nadia Khomami, "BP to End Tate Sponsorship after 26 Years," The Guardian (11 March 2016), online: $<$ www.theguardian.com/artanddesign/2016/mar/11>.

155 "COP21: Eco Activists Brandalism Launch Paris Ad Takeover," BBC News (29 November 2015), online: $<$ www.bbc.com/news/world-europe-34958282>.

156 Lekakis, supra note 144 at 312. 
Corporate logos are also targeted. As part of its campaign against BP, the Greenwash Guerrillas staged a culture-jamming stunt in which some fifty figures garbed in black entered the Tate Gallery each holding a BP-branded paint tube, which they placed on the floor in a circle and stamped on. The sprayed paint created an image on the floor echoing BP's "helios" corporate logo. In 2002, Greenpeace launched a climate change campaign against dirty oil and used images not of climate change impacts but, rather, of the Esso company logo and images of then US President George Bush to promote its message. ${ }^{157}$ Another Greenpeace action, involving a cleanup operation on a beach near Manila, Philippines, exposed the businesses responsible for the plastic debris collected by creating a banner that read "[p]olluted by ..." prominently showing the logos of the companies identified through the cleanup audit. ${ }^{158}$

The aesthetics of corporate governance itself has been spoofed. The artist collective called GCC (in reference to the Gulf Corporation Council from the Arabian Gulf nations, which it often parodies), staged a critique of the aesthetics of corporate governance in an elaborate travelling exhibition in $2014 .{ }^{159}$ The irreverent eight performance artists comprising the GCC gathered in a mock "global summit," mimicking the rituals of corporate aggrandizement and bureaucracy. The exhibition included a "waiting room" with a giant television screen projecting images of the GCC mission and congenial businessmen with calming voice-overs. Another room shows glossy photographs of staged settings, such as a high-level business summit overlooking scenic imagery of the Swiss Alps. Carefully contrived additions include a lavish conference table, decorated tissue boxes, glass trophies, and other paraphernalia reminiscent of the aesthetic of business meetings. The GCC's performances not only touch on the specific rituals of business deals in the Gulf states, but they also satirize the pomp and ceremony found in many business cultures worldwide.

With the massive growth in the corporate presence in cyberspace, anti-corporate activism has had to update its tactics. The advertising industry has changed with the Internet, relying less on billboards and television commercials to engage the public while shifting to online marketing campaigns via web newspapers and social media platforms. In the age of the Internet, some believe that social activism has been revolutionized by access to a new digital public space that enables activists to collaborate from local to global scales cheaply and effectively through email, social media, and webpages. ${ }^{160}$ The Internet has already shown itself to be conducive to the dissemination of subversive messages and images on a large scale and to be improving the coordination of protest actions, such as with the Occupy Movement. Cyberspace, however, also has limitations and cannot always be a substitute for direct culture jamming in physical public spaces. While the Internet empowers dissenting voices, it also just as strongly empowers listeners to tune out, by choosing their own web browsing and social media networks. ${ }^{161}$ Whereas street protests and culture jamming in markets, sidewalks, plazas, and other public spaces enable activists to directly confront the wider public, people have greater control in cyberspace over where they wish to roam

157 Julie Doyle, "Picturing the Clima(c)tic: Greenpeace and the Representation Politics of Climate Change Communication" in B Schneider \& T Nocke, eds, Image Politics of Climate Change (Berlin: Transcript Verlag, 2014$) 225$ at 239.

158 Sarah King, "My Week on a Plastic Beach Helping to Name and Shame Its Polluters," Greenpeace Canada (4 October 2017), online: <www.greenpeace.org/canada/en/story/405/my-week-on-a-plastic-beach-helping-to-name-and-shame-itspolluters>.

159 Alex Greenberger, “When Nations Become Brands: GCC on Tackling the Gulf Region's Values, and Gazing into the Area's Future," Art News (10 November 2016), online: <www.artnews.com/2016/11/10>.

160 Martha McCaughey, ed, Cyberactivism on the Participatory Web (London: Routledge, 2014).

161 Kohn, supra note 143, at 210 (referring to Andrew Shapiro's opinion). 
or what they wish to see. The Internet has also come under significant corporate control, through search engines that direct browsers to paid sponsors' webpages, and it gives corporations greater means of surveillance to identify and prosecute those who infringe their copyright or trademarks. ${ }^{162}$ And, in some countries, such as China, extensive Internet censorship limits dissenting voices.

Despite these obstacles, the Internet has become a major resource for digital activism, especially through social networking facilities such as Facebook and Twitter that allow for mobilizing supporters and publicizing actions worldwide. "Hactivism" has been coined to describe some forms of online culture jamming, which includes "web site defacements, redirects, denial-of-service attacks, information theft, website parodies, virtual sit-ins, [and] virtual sabotage." 163 Where website security cannot be breached, hactivists may create website clones. One example imitated the Dow chemical company's website with messages for reparation for the victims of the 1984 accident in Bhopal India. ${ }^{164}$ Another example is when Kieron Dwyer, a US comic artist, parodied Starbuck's famous mermaid logo with the message "consumer whore" inscribed on it, as distributed in comic magazines, T-shirts, and stickers that he sold. He was sued and settled out of court. ${ }^{165}$

\section{B. Impact and Influence}

We know much less about the efficacy of counter-aesthetics as a pedagogical tool. Certainly, some antics are highly publicized and directly observed by many. Further publicity comes from flow-on news coverage; Brandalism caught the attention of the mainstream media, some with sympathetic reporting, including stories in Huffington Post and the BBC. ${ }^{166}$ Through adverse publicity, culture jamming may help to undermine the targeted companies' social licence and thereby exert governance-like discipline to the extent that hurt businesses are compelled to genuinely improve their environmental performance. ${ }^{167}$ There may also be adverse economic repercussions from consumers or investors. One closely studied example is the Yes Men's impersonation of the Dow Jones on the BBC (discussed earlier), which gave the story direct media access and extensive publicity and, as a result, the company's share price temporarily plunged 4 percent. But the long-term effect of this hoax may have been minimal; researchers found that ironically the hoax appeared to reduce media coverage of the underlying environmental and health consequences of the Bhopal disaster because attention shifted to the Yes Men themselves. ${ }^{168}$ Culture jamming may even help the targeted businesses because its irreverent and rebellious qualities may

162 Ibid at 215.

163 Alexandra Samuel, Hactivism and the Future of Political Participation (PhD dissertation, Harvard University, Cambridge, MA, 2004) at iii.

164 Originally, Dow Chemical, online: <www.dow-chemical.com>, but the website was later shut down.

165 Sarah M Schlosser, "The High Price of (Criticizing) Coffee: The Chilling Effect of the Federal Trademark Dilution Act on Corporate Parody" (2001) 43 Arizona LR 931.

166 Cited in Lekakis, supra note 144 at 318.

167 Nina Hall et al, "Social Licence to Operate: Understanding How a Concept Has Been Translated into Practice in Energy Industries" (2015) 86 Journal of Cleaner Production 301.

168 The researchers found that "only 2 of the 17 articles discussing the Yes Men's hoax actually explored the health care situation in Bhopal, which was the entire point of the hoax." Nick W Robinson \& Gina Castle Bell, "Effectiveness of Culture Jamming in Agenda Building: An Analysis of the Yes Men’s Bhopal Disaster Prank" (2013) 78:4 Southern Communication Journal 352 at 363. 
be confused with the marketing style that some companies borrow to appeal to consumer niche subcultures. ${ }^{169}$

Other evidence suggests that culture jamming sometimes can hurt targeted businesses through public shaming. Consider Greenpeace's video parodying a Kit Kat commercial in 2010. The clip features a tired office worker who, upon hearing the brand's famous slogan "Have a break?," opens a Kit Kat wrapper to find not fingers of chocolate but the bloodied finger of an orangutan. The "advert" closes with viewers urged to "give the orangutan a break." "170 The prank was intended by Greenpeace to expose Nestlé's buying of palm oil (a key ingredient in Kit Kats and other products it makes) from destroyed rainforests once home to these apes and many other species. Nestlé's was put on the back foot by the Greenpeace stunt, which quickly went viral across the Internet. Within eight weeks, the company had agreed to Greenpeace's demands to change its suppliers of palm oil. ${ }^{171}$ Another success story is anti-coal campaigner Jonathan Moylan who in 2014 distributed a fake ANZ bank media release causing a AUS \$300 million slump in the market value of Whitehaven, a coal mining company. ${ }^{172}$ Moylan's goal was to publicize the ANZ's support for an environmental controversial mining project in Australia proposed by Whitehaven. Although the company's stock price recovered and the mine project went ahead, the publicity was damaging for the ANZ, which has since tightened its lending criteria for coal-mining projects. And although Moyan was successfully prosecuted by authorities for disseminating false information to the market, this simply gave his cause even greater publicity. ${ }^{173}$ Efforts by companies to counteract culture-jamming pranks can also backfire. Multinational coal-mining giant Xstrata sought to remove from YouTube a parodied mining commercial, which was created as part of an Australian trade union campaign against environmentally destructive mining, but Xstrata's demands simply reignited public interest and other YouTube users promptly reloaded the video on the Web. ${ }^{174}$

The impact of counter-aesthetic strategies must also be assessed against changes in government policy and law. Culture jamming aims not only to expose corporate malfeasance and enable consumers to make informed decisions, but it also serves to reduce the legitimacy of business in order to achieve better government laws and policies. One notable success is the Australian pioneer of culture jamming, the BUGA UP group, which began in the late 1970s to deface tobacco and alcohol billboards with graffiti to challenge public advertising of these drugs. Its efforts were instrumental not only in achieving such bans in Australia, the first major country to prohibit tobacco advertising, but it also "helped reframe the global

169 Christine Harold, “Pranking Rhetoric: 'Culture Jamming' as Media Activism” (2004) 21 Critical Studies in Media Communication 189.

170 Paul Armstrong, "Greenpeace, Nestlé in Battle over Kit Kat Viral," CNN (20 March 2010), online: $<$ http://edition.cnn.com/2010/WORLD/asiapcf/03/19/indonesia.rainforests.orangutan.nestle/index.htm>.

171 Yossi Sheffi, "Profits v Planet: Can Big Business and the Environment Get Along?" The Guardian (7 September 2018), online: <www.theguardian.com/environment/2018/sep/07>.

172 Sarah McVeigh, "I Wanted to Stop the Mine': Jonathan Moylan and the $\$ 300$ Million Hoax," ABC (Triple J) (3 October 2017), online: <www.abc.net.au/triplej/programs/hack/jono-moylan/9010874>.

173 Louise Hall, “Jonathan Moylan Avoids Jail Term for Fake ANZ Media Release About Whitehaven Coal,” Sydney Morning Herald (25 July 2014), online: <www.smh.com.au/national/nsw/jonathan-moylan-avoids-jail-term-for-fakeanz-media-release-about-whitehaven-coal-20140725-zwwe7.html $>$.

174 Ben Butler, "Xstrata Parody Leaves Mining Giant Fuming Yet Again," Sydney Morning Herald (24 April 2012), online: $<$ www.smh.com.au/business/xstrata-parody-leaves-mining-giant-fuming-yet-again-20120423-1xhac.html>. 
debate about tobacco control." 175 The hoax that Jonathan Moylan perpetrated against the ANZ bank and Whitehaven did not in itself change the law, but it did stimulate considerable scholarly and public debate about the value of civil disobedience as a legitimate means of political expression, and it increased pressure on the market regulator - the Australian Securities and Investment Corporation - and the major banks to dramatically improve their assessment and disclosure of climate change-related risks, which has improved recently. ${ }^{176}$

The courts have also occasionally been successfully used to defend culture jamming, with thus wider implications for upholding freedom of speech and protest on environmental issues. In the South African case of Laugh It Off Promotions $v$ South African Breweries International, the courts considered a claim of trademark infringement from a caricature of the Carling Black Label trademark, with the words "Black Labour, White Guilt" substituted for the words Black Label and Carling respectively, and imprinted by the defendant on T-shirts that were sold for commercial gain. Laugh It Off defended its actions, inter alia, as an exercise on constitutionally protected freedom of expression. In weighing the right of the trade mark proprietor against freedom of expression, the Constitutional Court concluded that the culture-jamming prank had no effect on the beer brewer's market dominance or sales, while the "valuable expressive rights" exercised by Laugh It Off "ought not to be lightly trampled upon by marginal detriment ... to the commercial value that vests in the mark itself." 177

Culture jamming may also have influence by directly taking a stance against the rampant consumerism afflicting the arts world itself. American arts commentator Hal Foster, a leading detractor of this commodification of the arts, excoriates those practitioners who valorize wealth and fame over artistic skill and message. ${ }^{178}$ While professional art markets emerged in Europe since the seventeenth century, they have surged since the 1950 s to become a "popular spectator sport" 179 for vain, cashed-up investors. ${ }^{180}$ The global art market reached a hefty US $\$ 45$ billion in sales in $2016 .{ }^{181}$ The rise of celebrity artists raking in the millions, notably Damien Hirst and Jeff Koons, can taint the arts world by putting pressure on many artists to cater to taste and fashion and, thus, skew attention away from certain kinds of work that might make a more valuable contribution to social change and action. The quality of the art itself can suffer under this commoditized aesthetic. ${ }^{182}$

175 Lachlann Partridge \& Arthur Chesterfield-Evans, "BUGA UP Founder Made Unique Push to Ban Tobacco Advertising," Sydney Morning Herald (20 March 2018), online: <www.smh.com.au/national/buga-up-founder-made-unique-push-toban-tobacco-advertising-20180318-h0xmmj.html>.

176 Matthew Rimmer, "Stand with Jono: Culture-Jamming, Civil Disobedience, and Corporate Regulation in an Age of Climate Change" in M Maloney \& N Rogers, eds, Law as If Earth Really Mattered: Wild Law Judgments (New York: Routledge, 2017) 293 at 314-320; Clancy Yeates, "ASIC Warns on Climate Risk as Heat Turns on Directors," Sydney Morning Herald (19 June 2018), online: <www.smh.com.au/business/banking-and-finance/asic-warns-on-climate-riskas-heat-turns-on-directors-20180618-p4zm7j.html>.

177 Laugh It Off Promotions CC v South African Breweries International (Finance) BV t/a Sabmark International and Another, Case CCT42/04, [2005] ZACC 7 at para 56.

178 Hal Foster, "The Medium Is the Market" in N Degen, ed, The Market (London: Whitechapel Gallery, 2003) 198.

179 Louisa Buck \& Philip Dodd, Relative Values or Art's Worth? (London: BBC Books, 1991) at 55.

180 Noah Horowitz, Art of the Deal: Contemporary Art in a Global Financial Market (Princeton, NJ: Princeton University Press, 2011).

181 "Welcome to the \$45 Billion Art Market," Artnet News (4 March 2017), online: <https://news.artnet.com/market/tefaf2017-art-market-report-880727>.

182 Fredric Jameson, Postmodernism, or, the Cultural Logic of Late Capitalism (Durham, NC: Duke University Press, 1991). 
These concerns, however, should not imply that the sale of art is intrinsically problematic. Full-time practitioners can hardly support themselves otherwise, especially given the diminishing public funding for the arts. Furthermore, art sales can directly support progressive politics, such as environmental nongovernmental organizations retailing coffee-table books, calendars, posters, music compact discs, and other aesthetic paraphernalia. The Audubon Society, the Sierra Club, Friends of the Earth, and other nature conservation champions routinely sell such wares that support the artists who create them. Furthermore, a number of art movements have sought to resist commodification even if they do not purport to serve culture jamming; Italian Arte Povera (meaning "poor art") has inspired artists to disdain consumerism by reusing everyday found objects, ${ }^{183}$ while Land Art and Conceptual Art has helped to dematerialize the art object and circumvent the omnipresent commercial museum and gallery culture. ${ }^{184}$

In sum, culture jamming offers a tool for dissent activists to counter the aesthetics of corporate behaviour, especially duplicitous conduct masquerading as CSR. It can supplement, but not replace, fairtrading regulation or trademark controls for several reasons, including the fact that non-state actors do not have the resources to comprehensively target all corporate malfeasance and, instead, must selectively challenge the biggest culprits. Culture jamming also has a negative stance, highlighting green illusions but hardly rewarding exemplary business conduct. Its main value is propagating a counter-aesthetics that squarely addresses the aesthetics of the business world in a way that eludes conventional regulation.

\section{REFLECTIONS ON FUTURE GOVERNANCE}

Aesthetics has a powerful hold on human culture, which the business sector exploits in its marketing and branding to masquerade as socially responsible. This visceral emotional and cultural power of aesthetics is reflected in enduring adages such as "seeing is believing," "a picture tells a thousand words," and "where words fail, music speaks." Fraudulent or deceptive environmental claims are thus not surprisingly amplified by corporate aesthetics embedded in trademarks, websites, product packaging, and general marketing. They are not easily subject to the control of law as a text-based discipline. Fair trading and trademark law ostensibly encompass the audio-visual dimensions of corporate marketing and branding, yet they can struggle to recognize and discipline some aesthetic dimensions of business communications and fail entirely to resist the broader consumerist impulse. The law simply cannot see the trees for the forest. When marketing practices and legal doctrine operate in different realms, we can start to appreciate that CSR aesthetics present a serious challenge to regulators.

Beyond officialdom, a dissident social movement that challenges corporate malfeasance has emerged. Counter-aesthetic strategies artfully transform corporate expressive material - slogans, songs, logos, billboards, or other elements of the business brand - into something subversive. With humour and hoaxing, counter-aesthetics can expose deceptive corporate practices that degrade the environment or unveil other social issues of concern. These culture-jamming strategies also face legal impediments of their own, however, including diminishing access to public spaces, restrictions on freedom of speech, defamation law, and companies' stentorian enforcement of their intellectual property rights.

183 Charlene Cerny \& Suzanne Seriff, eds, Recycled Re-Seen: Folk Art from the Global Scrap Heap (Santa Fe: Museum of International Folk Art, 1996).

184 Thomas McEvilley, The Triumph of Anti-Art: Conceptual and Performance Art in the Formation of Post-modernism (New York: McPherson \& Company, 2005). 
The primary contribution of this article to the scholarship on CSR is not to offer concrete solutions to the foregoing governance gaps and deficits, which are very difficult to solve, but at least to introduce novel ways of understanding how CSR practices pose difficulties for regulators and to highlight the contributions that non-state actors are making through their subversive counter-aesthetics. By illuminating the aesthetic dimensions of CSR and identifying weaknesses in the law, this article hopes to spur deeper reflection and scholarly debate on the problems created by CSR aesthetics and how to educate the public and change consumer behaviour. In sketching a future agenda for the law itself, its role in relation to counter-aesthetics should be considered.

Reclaiming and protecting the public sphere for community discourse and aesthetic expression are crucial for the foregoing agenda. The decline of the public realm, a space supposedly insulated from the economy, household, or the state apparatus, was observed by Hannah Arendt back in the 1950s in her classic The Human Condition, in which she observes that its decline deprived citizens of "spaces of appearance" for engaging with their peers in political discourse and civic action. ${ }^{185}$ Likewise, German philosopher Jurgen Habermas has defended the public sphere as a crucial site for public deliberation and rational discourse for the pursuit of common ethical and social concerns. ${ }^{186}$ When commentators bemoan the "McDonaldization" or "Disneyification" of society, they are speaking precisely about the corrosive corporate inroads into this public realm. ${ }^{187}$ Stjepan Mestrovic's prescient book on the Postemotional Society warns of the risks to individual's faculty for authentic emotional experiences by their incessant exposure to a hyper-aestheticized consumer culture. ${ }^{188}$

Public spaces such as town squares, plazas, parks, sidewalks, and other areas open for people to freely mingle and converse are threatened by aestheticized commerce and consumerism that enjoys legal protection. Shopping malls, which have become one of the primary "public" gathering places in modern society, with over 45,000 established in the United States since the $1950 \mathrm{~s},{ }^{189}$ are commonly managed by their proprietors as private spaces with restrictions placed on what patrons can wear, say, or do and policed by private security forces. American courts have determined that the constitutional rights of freedom of expression do not extend to shopping malls, which are deemed not to be equivalent to public places such as the town square. ${ }^{190}$ Anti-protest legislation, adopted in several Australian states in recent years, is another legal contrivance that is shrinking the public space in which one can challenge unscrupulous business practices. ${ }^{191}$ Consumer and investor protection law is also being used to silence culture jammers (as against green-washing companies); Jonathan Moylan was charged under section 1041E of the Corporations Act 2001 for making false and misleading statements associated with his prank against the

185 Hannah Arendt, The Human Condition (Chicago: University of Chicago Press 1958).

186 Jurgen Habermas, The Structural Transformation of the Public Sphere, translated by T Burger (Boston: MIT Press, 1991).

187 George Ritzer, McDonaldization of Society (Thousand Oaks, CA: Pine Forge Press, 2001); Alan Bryman, The Disneyifiication of Society (London: Sage Publications, 2004).

188 Stjepan Mestrovic, Postemotional Society (London: Sage Publications, 1997).

189 William S Kowinski, The Malling of America: Travels in the United States of Shopping (Bloomington, IN: Libris, 2002).

190 Kohn, supra note 143, at 1, 70-74.

191 Leah White \& Bruce MacKenzie, "New Protest Regulations Labelled ‘A Fundamental Attack on Democracy' Will Start in NSW from July 1," ABC News (26 June 2018), online: <www.abc.net.au/news/2018-06-26/new-protest-regulationslabelled-attack-on-democracy/9905676>. 
ANZ bank and the Whitehaven coal-mining company. ${ }^{192}$ Through these and other legally sanctioned stances, "the opportunities for political conversation are diminished," explains American political scientist Margaret Kohn. ${ }^{193}$ Public speaking, demonstrations, leafleting, and petitioning, which allow for direct engagements and live debates, are pushed further aside.

While the Internet has created a new type of public space, as discussed earlier in this article, it has limitations to substituting for intimate and direct encounters. As Kohn summarizes, "[f]ace-to-face political debate allows for citizens to ask questions and challenge answers. Furthermore, the politics of public space requires few resources and therefore allows marginal viewpoints to be expressed [and] debated." "194 Twitter "debates," blogs, or email exchanges do not allow for participants to come together in a shared realm, and, in fact, they have often become simply another arena for corporate marketing. The private nature of website hosting and browsing also makes it difficult for third parties to hijack advertisements to propagate their political discourse.

Encouragingly, some interesting legal precedents that are putting the breaks on corporate aesthetics have emerged in some localities. Some municipalities are restricting intrusive advertising. The city of Sao Paolo, Brazil, home to twelve million, has banned billboards and posters in public areas including buses and trains since 2007 to rid the city of "visual pollution." 195 The city of Canberra, Australia, has likewise maintained a long-standing ban on marketing billboards to the overwhelming approval of its residents. ${ }^{196}$ Indeed, a global movement to restrict the proliferation of outdoor advertising has been identified in recent years, with the law being used to roll-back aesthetic pollution in Chennai (India), Tehran, and Paris, ${ }^{197}$ And, in 2014, Farida Shaheed, the United Nations special rapporteur in the field of cultural rights, called on governments to protect their societies "from undue levels of commercial advertising and marketing while increasing the space for not-for-profit expressions." 198

Intellectual property law must also be reconciled with the need to protect freedom of expression and protest in an open democracy. Culture-jamming actions can be viewed as an infringement of trademarks or copyright protected works as well as the creator's moral rights of attribution of authorship. Researchers have recommended that legislators create more generous "fair use" exceptions for defined spheres of activity such as culture jamming. ${ }^{199}$ Australia's Copyright Act 1968 was amended in 2006 to protect those

192 Hall, supra note 173.

193 Kohn, supra note 143, at 2.

194 Ibid at 4.

195 Andrew Downie, “São Paulo Sells Itself," Time (8 February 2008), online:

$<$ http://content.time.com/time/specials/2007/article/0,28804,1709961_1711305_1860002,00.html>.

196 Emily Baker, "Canberra Billboard Ban: New Polling Shows Disapproval for Re-laxing of Laws," Canberra Times (18 February 2018), online:

$<$ www.canberratimes.com.au/national/act/canberra-billboard-ban-new-polling-shows-disapproval-for-relaxing-of-laws20180218-h0w9ma.html>.

197 Arwa Mahdawi, "Can Cities Kick Ads? Inside the Global Movement to Ban Urban Billboards," The Guardian (13 August 2015), online: <www.theguardian.com/cities/2015/aug/11/can-cities-kick-ads-ban-urban-billboards>.

198 United Nations Human Rights, "UN Expert in Cultural Rights Calls for Greater Scrutiny and Control of Commercial Advertising," media release (28 October 2014), online:

$<$ www.ohchr.org/EN/NewsEvents/Pages/DisplayNews.aspx?NewsID=15229\&LangID=E>.

199 Brian Fitzgerald \& Damien O'Brien, "Digital Sampling and Culture Jamming in a Remix World: What Does the Law Allow?" in B. Fitzgerald, Jessica Coates \& Suzanne Lewis, Suzanne, eds, Open Content Licensing: Cultivating the Creative Commons (Sydney: Sydney University Press, 2007) 156. 
manipulating copyright material for the fair use purpose of parody and satire, although with amendments that also made it easier to sustain criminal prosecution against unlawful infringements. ${ }^{200}$ As noted earlier, the South African courts in the Laugh It Off case have already sided with the culture jammer's rights of expression. ${ }^{201}$ Several US cases have also condoned parodying business trademarks as protected noncommercial free speech so long as parodying does not devalue the mark by affecting consumer preferences - an outcome, of course, that is often the ultimate purpose of culture jamming. ${ }^{202}$

In closing these brief reflections on future governance directions, improving the legal milieu for culture jamming will not solve all of the problems associated with CSR aesthetics. Culture jamming itself, as an art form, is also unlikely to change the environmental policies and laws of governments. The arts can contribute to public discourse and open human imagination in novel and interesting ways for critiquing environmental practices, but they depend on other actors and processes taking additional steps to transform corporate and government behaviour, whether through consumer boycotts, public interest litigation, or other interventions. As Chinese artist Ai Weiwei puts it, "art is a social practice that helps people to locate their truth" - to find the truth behind green illusions, for instance, and thereby maybe to one day hold business moguls and politicians accountable for their follies. ${ }^{203}$ The counter-aesthetics of culture jamming helps to reveal another reality of business and consumerism that gives us the novel and critical insight to better challenge their environmental impacts.

200 Copyright Act 1968 (Cth), ss 103AA, 132AA-AT.

201 See note 183 above.

202 See e.g. Mattel Inc v Walking Mountain Prods, 353 F3d 792 (9th Cir 2003); see also Evelyn McDonnell, "Never Mind the Bullocks: Shepard Fairey's Fight for Appropriation, Fair Use, and Free Culture" in M DeLaure, M Fink \& M Dery, eds, Culture Jamming: Activism and the Art of Cultural Resistance (New York: New York University Press, 2017) 179 at $188-189$.

203 Ai Weiwei, “Ai Weiwei: 'Every Day in China, We Put the State on Trial,” The Guardian (16 April 2013), online: $<$ www.theguardian.com/commentisfree/2013/apr/15/ai-weiwei-china-state-on-trial $>$. 